Universidade de Brasília - UnB

Faculdade de Medicina - FM

Programa de Pós-graduação em Ciências Médicas - PPGCM

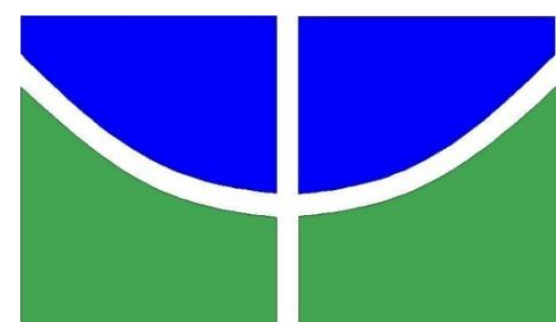

\title{
Pesquisa de Mutações no Gene ROR2 em Pacientes com a Forma Recessiva da Síndrome de Robinow
}

Ariadne Ramalho de Lima

Dissertação apresentada ao Programa de Pós-graduação em Ciências Médicas da Universidade de Brasília como requisito parcial para obtenção do título de Mestre em Ciências Médicas.

Orientadora: Dra. Juliana Forte Mazzeu de Araújo 


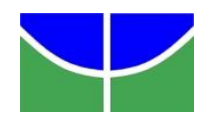

Universidade de Brasília

Faculdade de Medicina

Programa de Pós-graduação em Ciências Médicas

Dissertação de Mestrado

ARIADNE RAMALHO DE LIMA

Título:

\title{
Pesquisa de Mutações no Gene ROR2 em Pacientes com a Forma Recessiva da Síndrome de Robinow
}

\author{
Comissão Examinadora: \\ Prof. Dra Juliana Forte Mazzeu Araújo \\ Faculdade de Medicina-UnB \\ Prof. Dra Ana Carolina Acevedo Poppe \\ Faculdade de Saúde- UnB \\ Dr Daniel Rocha de Carvalho \\ Rede Sarah de Hospitais de Reabilitação \\ Dra Pollyanna Almeida Costa dos Santos \\ Faculdade de Saúde- UnB \\ Suplente
}

Brasília, 03 de julho de 2015 


\section{Agradecimentos}

Gostaria de agradecer primeiramente a Deus por seu amor, sua graça, sabedoria por ter me conduzido durante todo o desenvolvimento desse projeto por me presentear com incomparável oportunidade de conhecer pessoas incríveis, adquirir conhecimento único e permitir com que realizasse um grande sonho de trabalhar com pesquisa científica.

Minha mãe Roselaine Ramalho de Lima por ser fonte de determinação, incentivo, amor, dedicação e apoio de todos os dias desde o início até o final da realização do trabalho. Meu pai José Luis de Lima por ser um exemplo de vida, por todo o amor, atenção, apoio, dedicação agradeço a vocês meus queridos por tudo por serem meus heróis. Meu irmão João Pedro Ramalho de Lima por escutar todas as minhas explicações e treinamento de apresentações de trabalhos.

Meu esposo Filipe V. da S. Viana por estar ao meu lado em todos os momentos pelo grande incentivo, força, determinação, carinho, amor. Pela tradução dos inúmeros artigos científicos, almoços no restaurante universitário com direito ao brigadeiro no final, por aguardar horas no laboratório comigo até os experimentos terminarem. Obrigada por tornar o desenvolvimento desse trabalho mais tranquilo e prazeroso.

Minha irmã Mariana Ramalho e Alison Horst por me receber em sua casa durante a etapa final do trabalho, por ser minha melhor amiga, pelo seu amor, carinho, determinação, preocupação, por estar ao meu lado durante um dos momentos mais críticos da minha vida. Minha prima Letícia Ramalho Brittes por me ajudar com a tradução para inglês do meu artigo científico, pela sua atenção e amor e carinho. Minha prima Rafaela Ramalho Guerra por acompanhar e fazer parte dessa jornada, por realizar auxílio em todo processo de purificação das amostras para sequenciamento, por sua dedicação, atenção e amor.

Minha respeitável orientadora Dra Juliana Forte Mazzeu de Araújo, admirável profissional dedicada, humana, conduziu o desenvolvimento desse trabalho com segurança e perspicácia sempre buscando com calma soluções para os problemas que surgiam além de ter paciência e sabedoria para lidar com momentos difíceis e sempre tirar as dúvidas por mais simples que elas fossem, se mostrando uma grande Mestre, orientadora, professora.

Toda equipe técnica do laboratório de Genética da Faculdade de Medicina, técnicos Aluísio e Nilsa, estagiária Bárbara, Dra Iris Ferrari, mestranda Diana, Marcella pelas conversas e discussões dos projetos. Ao Programa de Pós Graduação em Ciências Médicas da Faculdade de Medicina da Universidade de Brasília por todo suporte acadêmico e administrativo. Incentivo financeiro da CAPES pelo fornecimento da bolsa de aluno mestrando do programa.

A todos vocês meus familiares, amigos, professores queridos dedico a conclusão desse trabalho como reconhecimento da participação de todos na construção desse sonho que se tornou realidade e se conclui com sucesso, meu muito obrigada a todos. 


\section{Resumo}

A Síndrome de Robinow se caracteriza por dismorfias faciais associadas a encurtamento mesomélico e genitália hipoplásica. Defeitos de segmentação costovertebral que incluem fusões de costelas também podem ser observados e permitem distinguir os pacientes com a forma autossômica recessiva da síndrome daqueles com a forma autossômica dominante. A forma recessiva é causada por mutações no gene ROR2 (related orphan receptor 2), sendo que apenas dezenove diferentes mutações foram descritas em pacientes com a síndrome. O objetivo desse trabalho foi identificar novas mutações no gene ROR2 em pacientes com a Síndrome de Robinow autossômica recessiva. Foram selecionados onze pacientes originários do Brasil, Estados Unidos, Índia e Turquia com características clínicas da forma recessiva da síndrome. O sequenciamento foi realizado a partir de amostras de sangue e saliva por sequenciamento Sanger, ou por sequenciamento de nova geração na plataforma Ion PGM. Em um paciente a mutação foi detectada por MLPA. Identificamos 13 diferentes mutações sendo que 10 ainda não haviam sido descritas na literatura. A comparação dos dados clínicos dos pacientes estudados com as frequências dos sinais clínicos proposta por Mazzeu e cols. (2007) revelou frequência semelhante para a maioria dos sinais clínicos com exceção da fusão de costelas, ausente no paciente 5, a língua bífida presente em todos os 11 pacientes, o lábio superior fino que teve uma frequência de $72 \%$ e anteriormente era de $26 \%$ e a má-oclusão dentária que teve uma frequência de $60 \%$ enquanto que a frequência descrita anteriormente era de $93 \%$. Assim, a descrição clínica detalhada de pacientes com diagnóstico confirmado molecularmente contribuiu para a definição das frequências dos principais sinais clínicos nessa forma da síndrome. Observamos também uma maior gravidade das manifestações esqueléticas nos pacientes com mutações que alteram o quadro de leitura mostrando assim que pode haver correlação entre o tipo de mutação e o fenótipo dos afetados. O conjunto de novas mutações detectadas no trabalho colaboram para um melhor entendimento da fisiopatologia da síndrome. 


\begin{abstract}
Robinow syndrome is characterized by facial dysmorphisms, mesomelic limb shortening and hypoplastic genitalia. Costovertebral segmentation defects including rib fusions may be present and allow the distinction between the autosomal recessive and the autosomal dominant forms. Recessive form is caused by mutations in ROR2 gene (related orphan receptor 2) and only 19 different mutations have been described in the literature in patients with the syndrome. The main goal of this work was to identify new mutations in ROR2 in patients with RRS. Eleven patients with clinical signs of RRS from Brazil, United States, India and Turkey have been selected. Sequencing was performed from either blood or saliva samples by Sanger sequencing or Next generation sequencing using Ion PGM platform. In one patient the mutation was detected by MLPA. We identified 13 different mutations, 10 not previously described in the literature. Comparison of clinical data from our patients and the frequencies of clinical signs proposed by Mazzeu e cols., (2007) revealed similar frequencies for most clinical signs except for rib fusions, absent in patient 5; bifid tongue, present in all 11 patients; thin upper lip that had a frequency of $72 \%$ compared to $26 \%$ in the previous report and dental malocclusion that showed a frequency of $60 \%$ and the previous frequency was 93\%. Therefore, a detailed clinical description of patients with a molecularly confirmed diagnosis contributed to the definition of frequencies of the main clinical signs of the syndrome. We also observed a more severe skeletal phenotype in patients with frameshift mutations showing that genotype and phenotype may correlate. The group of new mutations detected in the present work contribute to a better understanding of the physiopathology of the syndrome.
\end{abstract}




\section{Lista de Abreviaturas}

DNA - $\quad$ Ácido desoxirribonucleico

PCR $\quad-\quad$ Reação em cadeia da Polimerase

RNA - $\quad$ Ácido ribonucleico

DNTPs _ - D Desoxirribonucleotídeos

ROR2 - Receptor tyrosine kinase-like orphan receptor 2

SR $\quad$ - $\quad$ Síndrome de Robinow

SRR _ - Síndrome de Robinow autossômica Recessiva

DRS _ - Síndrome de Robinow autossômica Dominante

WNT5A - $\quad$ Wingless-type MMTV integration site family, member $5 A$

SSCP $\quad-\quad$ Polimorfismo conformacional de fita simples

DVL1 - $\quad$ Dishevelled segment polarity protein

CAM-1 - Canal-associated neurons abnormal migration

$\mathrm{PCP} \quad-\quad$ Polaridade celular planar

LRP6 - $\quad$ Receptor de lipoproteína 6

$\begin{array}{lll}\text { PTK7 } & - & \text { Proteína Tyr quinase } 7\end{array}$

RYK - $\quad$ Receptor de quinase Tyr

COVESDEM $\quad-\quad$ Costovertebral segmentation defects with mesomelia

MLPA $\quad-\quad$ Multiplex Ligation-dependent Probe Amplification

DSH - $\quad$ - Dishevelled da Drosophila 
Índice

Resumo

Abstract

Lista de Abreviaturas

I. Introdução 1

I.1 Síndrome de Robinow 1

I.2 Manifestações clínicas $\quad 2$

I.3 Etiologia da Forma Autossômica Recessiva 3

I.4 Gene ROR2

I.5 Etiologia da Forma Autossômica Dominante 8

I.6 Interação funcional das proteína WNTs com o receptor ROR2 10

II. Objetivo 12

II.1 Objetivos específicos 12

III. Material e Métodos 13

III.1 Seleção dos pacientes 13

III.2 Material biológico 13

III.3 Triagem de mutações no gene ROR2 14

III.3.1 Extração de DNA 14

III.3.2 PCR . Reação em cadeia pela polimerase 15

III.3.3 Sequenciamento Sanger 17

$\begin{array}{ll}\text { III.3.4 Ion Torrent } & \\ & \mathrm{TM} \\ \mathrm{PGM}^{\mathrm{TM}} & 18\end{array}$

$\begin{array}{ll}\text { III.3.5 MLPA } & 21\end{array}$

IV. Resultados e Discussão 27

IV.1 Descrição clínica

IV.2 Diagnóstico Molecular $\quad 41$ 


\section{Índice de Figuras}

Figura 1: A. A,B,C,D preparações do esqueleto do coluna vertebral do recém-nascido. $(\mathrm{A}, \mathrm{B})$ tipo selvagem Wnt $(\mathrm{B}, \mathrm{C}) \mathrm{ROR} 2$ - / - ratos corado com vermelho de alizarina /Azul Alcian. B. M, N: expressão ROR2 no membro anterior de embriões em estágios $\mathrm{E} 12.5(\mathrm{M})$ e $\mathrm{E} 14.5(\mathrm{~N})$

Figura 2: Representação estrutural da proteína tirosina quinase ROR2 com apresentação de seus domínios extracelular e intracelular.

Figura 3: Representação esquemática da proteína ROR2, comparação da conservação de domínios em ortólogos já encontrados

Figura 4: Representação esquemática estrutural da ligação do receptor ROR2 e proteína Wnt e a possível via de sinalização PCP (polaridade celular planar).

Figura 5: Resultado da amplificação do exon 2 do gene ROR2. 1- Marcador de peso molecular, 2- Controle negativo, 3-6 Amostras de pacientes.

Figura 6: Análise de número de cópias do gene ROR2 por MLPA. As setas indicam a deleção em homozigose dos exons 4 e 5 do gene.

Figura 7: Resultados do sequenciamento sanger dos pacientes 7, 8 e 9.

Figura 8: Resultados do MLPA realizado no paciente 10 com deleções nos exon 4, 5.

Figura 9: Estrutura do receptor ROR2 com troca de aminoácidos a. já descritas na literatura no lado esquerdo da figura. b. mutações não descritas detectadas nos pacientes participantes da pesquisa

Figura 10: Paciente 1 aos seis anos. 
Figura11: a/b Imagens radiológicas da paciente 1 aos seis anos de idade

Figura 12: a/b Paciente 2 aos 39 anos de idade

Figura 13: Paciente 3 aos três anos de idade

Figura 14: a/b Paciente 4 aos 6 e 10 anos de idade.

Figura 15: Heredograma do paciente 4

Figura 16: a/b Paciente 6 aos 12 anos de idade.

Figura 17: Paciente 6 aos 12 anos de idade.

Figura 18: Raio x rádio e ulnas encurtados.

Figura 19: a/b metacarpianos e falanges curtas

Figura 20: Heredograma do paciente 6.

Figura 21: Figura 21: a/b a) Irmã do paciente 7 também afetada b) Paciente 7

Figura 22: Heredograma do paciente 7

Figura 23: a/b/c da paciente 8 aos 10 anos de idade.

Figura 24: Heredograma da paciente 8

Figura 25: a/b/c do paciente 9 aos cinco anos e seis meses de idade

Figura 26: Heredograma do paciente 9.

Figura 27: a/b paciente 10

Figura 28: a/b do paciente 11 


\section{Índice de tabelas}

Tabela 1: Primers utilizados para amplificação da região codificante do gene ROR2.......

Tabela 2: Descrição das mutações detectadas nos pacientes participantes da pesquisa com identificação do exon com alteração, tipo de mutação, alteração de base, proteína, domínio alterado e origem étnica.

Tabela 3: Tabela de mutações já descritas na literatura em pacientes com a síndrome de Robinow na forma autossômica recessiva

Tabela 4: Lista das características fenotípicas mais frequentes em pacientes portadores da síndrome de Robinow forma autossômica recessiva e o enquadramento das observações de cada paciente de acordo com a lista. 


\section{Introdução}

\section{I.1 Síndrome de Robinow}

A primeira descrição da síndrome de Robinow (S.R.), também conhecida como "Síndrome da Face Fetal", foi relatada por Robinow e cols., em 1969, na publicação“ A newly recognized dwarfing syndrome", ao observar os filhos de um casal não consanguíneo que apresentavam características como nanismo mesomélico, genitália hipoplásica e anomalias faciais: hipertelorismo, fissuras palpebrais alargadas, nariz curto e anomalias dentárias. O relato de outros prováveis afetados de ambos os sexos em gerações precedentes sugeriu a forma de herança autossômica dominante da síndrome (SRD).

Em continuidade às primeiras publicações sobre a Síndrome de Robinow, Wadia e cols em 1978, sugerem a forma de herança autossômica recessiva ao descreverem anomalias faciais e defeitos de segmentação costovertebral em dois pacientes filhos de um casal consanguíneo, apresentando assim uma forma de nanismo mesomélico agregado as anomalias faciais. Esta síndrome recebeu o acrônimo COVESDEM (costovertebral segmentation defects with mesomelia). No ano seguinte reconheceu-se que a síndrome COVESDEM era uma variante da S.R (SRR).

Em 1982 Shprintzen e cols relatam o primeiro caso de transmissão de pai para filho excluindo a hipótese do mecanismo de herança ligada ao X, reafirmando então as formas de herança dominante e recessiva descritas por Robinow e Wadia.

A incidência da síndrome de Robinow não é conhecida, devido à baixa apresentação de casos descritos na literatura. Uma maior frequência da forma autossômica recessiva da síndrome foi observada em populações da Turquia e Oman, regiões que apresentam alto índice de casamentos consanguíneos; cerca de $80 \%$ dos afetados pela forma recessiva são fruto de casamentos consanguíneos. A baixa 
incidência da síndrome pode ser atribuída também a um subdiagnóstico de muitos casos, gerado pela grande variabilidade clínica entre os pacientes, o que torna o diagnóstico clínico diferencial complexo e a necessidade de uma descrição completa do fenótipo dos afetados (Aksit e cols., 1997).

Dentro desse contexto a observação das manifestações clínicas apresentadas pelos pacientes torna-se essencial para o diagnóstico clínico tanto para a determinação da forma de herança autossômica recessiva ou autossômica dominante quanto para o diagnóstico diferencial com síndromes que apresentam manifestações clínicas semelhantes (Patton e cols., 2002).

\section{I.2 Manifestações clínicas}

As principais manifestações clínicas apresentadas pelos pacientes diagnosticados com a síndrome de Robinow são dismorfias faciais associadas a encurtamento mesomélico e genitália hipoplásica. A expressividade da síndrome é variável e o hipertelorísmo e a baixa estatura são os sinais mais marcantes da síndrome. Abaixa estatura é mais acentuada nos indivíduos com a forma autossômica recessiva que também podem apresentar defeitos de segmentação costovertebral que incluem fusões de costela. Já os pacientes com a forma autossômica dominante, podem apresentar estatura normal e acometimento cardíaco e renal (Mazzeu e cols., 2007).

Frente à dificuldade de diagnóstico clínico diferencial das duas formas da Síndrome de Robinow, Mazzeu e cols., em 2007, realizaram um trabalho com um protocolo para exames clínicos baseado em descrições de sinais e sintomas clínicos anteriores com uma avaliação da frequência de 75 sinais e sintomas clínicos presentes em pelo menos $5 \%$ do total de pacientes avaliados. Foram avaliados 88 pacientes novos e da literatura sendo 37 com SRR e 51 com SRD. O diagnóstico baseou-se na presença 
de baixa estatura ou encurtamento dos membros, qualquer grau de hipoplásia genital e avaliação da face incluindo o hipertelorísmo. Foram observadas as frequências de 75 sinais clínicos em pacientes com SRR e SRD e definidos aqueles que definiam melhor cada uma das formas da síndrome.

Hoje o diagnóstico diferencial das formas da Síndrome de Robinow está bem descrito quando se avalia um grupo de informações obtidas como histórico familiar, apresentação dos sinais clínicos, seu enquadramento dentro do grupo de sinais clínicos já observados para cada variante da síndrome e técnicas moleculares de diagnóstico que são uma ferramenta indispensável para confirmação da suspeita clínica (Fatih e cols., 2005).

Diagnóstico clínico diferencial entre a síndrome de Robinow e outras síndromes como as de Langer, Leri-Weill, Aarskog e Opitz, ainda pode ser difícil visto que algumas apresentam encurtamento de membros e baixa estatura associada à hipoplasia genital, alterações clínicas semelhantes às que acometem os pacientes afetados pela síndrome de Robinow (Robinow e cols., 1993).

\section{I.3 Etiologia da Forma Autossômica Recessiva}

Após os estudos de Robinow e Wadia descrevendo uma nova síndrome de nanismo, outros trabalhos são publicados relatando novos achados clínicos em pacientes com a forma autossômica recessiva da síndrome. Os principais sinais clínicos da forma recessiva da SR incluem baixa estatura, encurtamento mesomélico de membros, fusão de costelas, braquidactilia, defeitos cardíacos congênitos, hipoplasia genital e uma aparência facial dismórfica. A aparência facial inclui fronte proeminente, hipertelorismo, hipoplasia facial, boca larga e nariz curto com narinas antevertidas. As 
anomalias orais incluem hiperplasia gengival, anormalidades dentárias e fenda lábio palatina (Mazzeu e cols., 2007).

Por ser uma displasia esquelética grave que promove anomalias esqueléticas acentuadas que levam ao acometimento da estrutura óssea de seus afetados a forma autossômica recessiva da síndrome de Robinow tem instigado pesquisadores a buscarem a melhor compreensão dos mecanismos envolvidos no fenótipo da síndrome. $\mathrm{Na}$ busca da causa genética da síndrome Afzal e cols em 2000, realizaram o mapeamento por homozigose para identificar o gene envolvido na síndrome de Robinow autossômica recessiva, por meio de uma ampla pesquisa do genoma envolvendo cinco famílias de casais consanguíneos e descendentes afetados pela síndrome de Robinow autossômica recessiva. A única região de homozigose comum ocorreu em um segmento de 3-4 CM na região 9q22, entre os marcadores D9S1836 e D9S1803 (Afzal, e cols., 2000).

Os mesmos autores deram continuidade ao estudo para localizar o gene no intervalo identificado, a partir da análise de polimorfismo conformacional de fita simples (SSCP) e sequenciamento e identificaram mutações nos exons 5,7 e 9 do gene ROR2 em 26 dos 27 pacientes investigados. Simultaneamente, Van Bokhoven e cols 2000, encontraram mutações nos exons 5, 8 e 9 por sequenciamento em onze famílias com afetados pela SRR (Afzal, e cols., 2000).

Em 2004, Schwabe e cols, realizaram um significativo trabalho em modelo animal apresentando uma detalhada análise em camundongos nocaute Ror2 - / - comparando com o desenvolvimento dos sinais clínicos apresentados por afetados pela forma recessiva da síndrome de Robinow. Análise da expressão de Ror2 na região craniofacial foi realizada em embriões em diferentes fases de desenvolvimento. Nas imagens abaixo podemos observar as alterações ósseas encontradas. 

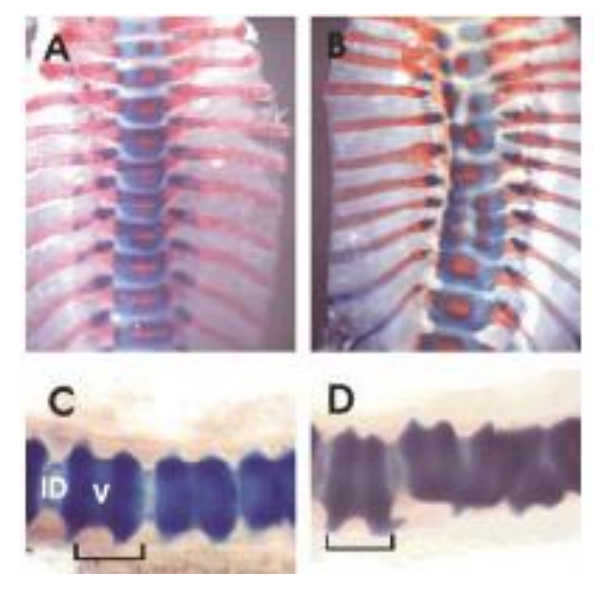

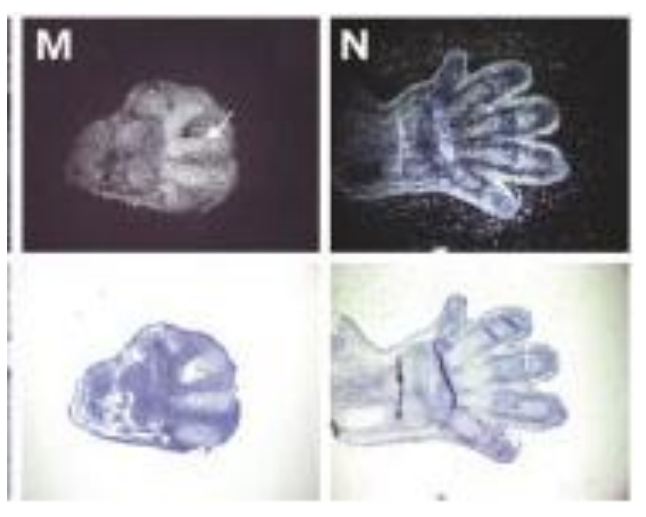

Figura 1: A. A,B,C,D preparações do esqueleto da coluna vertebral do recém-nascido. (A,B) tipo selvagem Wnt (B,C) Ror2 - / - ratos corado com vermelho de alizarina /Azul Alcian.B. M, N: expressão Ror2 no membro anterior de embriões em estágios E12.5 (M) e E14.5 (N). Adaptado de Schwabe e cols., 2004.

O estudo em modelo animal ressalta a importância da expressão do gene Ror2 nas fases iniciais da embriogênese, sua influencia na formação óssea e a atividade das proteínas Wnts durante o processo. Esses achados sugerem a possível interação entre Wnts e Ror2 e sua interferência no desenvolvimento das manifestações clínicas apresentadas por afetados pela forma autossômica recessiva da síndrome de Robinow e fornecem evidências para a melhor compreensão dos processos intracelulares que desencadeiam a clínica dos afetados (Schwabe e cols., 2004).

\section{I.3.1. Gene ROR2}

O gene ROR2 (receptor tyrosine kinase-like orphan receptor 2), está localizado em 9q22.2, possui cerca de $222 \mathrm{~kb}$ é constituído de nove exons e transcreve um RNAm de 4092 b. A proteína ROR2 possui 943 aminoácidos e é um membro da família dos 
receptores órfãos com atividade de tirosina quinase. As proteínas tirosina quinases como a codificada pelo gene ROR2 desempenham um papel na sinalização intracelular e servem de receptores para fatores de crescimento que controlam a multiplicação e diferenciação celular (Ali e cols., 2007).

O mecanismo geral de ativação funciona pela ligação do ligante ao domínio de ligação extracelular SH2 estimulando a dimerização do receptor o que resulta na fosforilação da tirosina alvo levando ao recrutamento de proteínas sinalizadoras que ativam uma cascata de sinal intracelular. Esses receptores possuem três domínios extracelulares: um domínio semelhante ao da imunoglobulina Ig-like, um domínio rico em cisteina e um domínio Kringle. Os dois domínios intracelulares que tem atividade de tirosina quinase são ricos em serina e treonina e um domínio rico em prolina, como mostrado na Figura 2 (Schlessinger e cols., 2000).

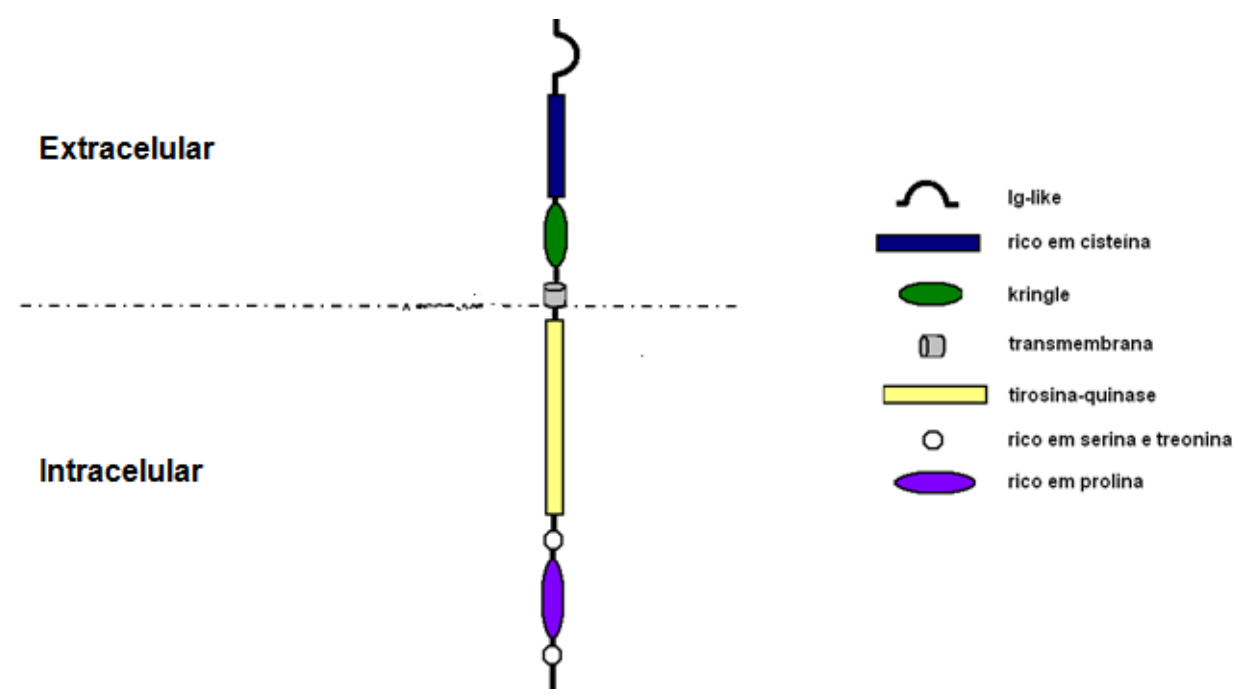

Figura 2: Representação estrutural da proteína tirosina quinase ROR2 com apresentação de seus domínios extracelular e intracelular.

Minami e cols em 2010 ressaltam a presença de ortólogos do gene ROR2 em outras espécies como Drosophila melanogaster Dror (Ror1) e Dnrk (Ror2), o receptor Dror não possuindo os domínios Ig-like, rico em serina e treonina ou rico em prolina. Em C. elegans foi identificado um único ortólogo, cam-1 (canal-associated neurons 
abnormal migration), cujo produto não possui um dos domínios ricos em serina e treonina nem o domínio rico em prolina.

Forrester e cols., em 2002 trabalham com a conservação dos domínios comuns do receptor tirosina quinase Ror2 encontrados em ortólogos já descritos anteriormente comparando assim a estrutura do receptor em cada ortólogo e realizando uma retrospectiva de informações sobre a conservação dos domínios para cada ortólogo como mostra a Figura 3.

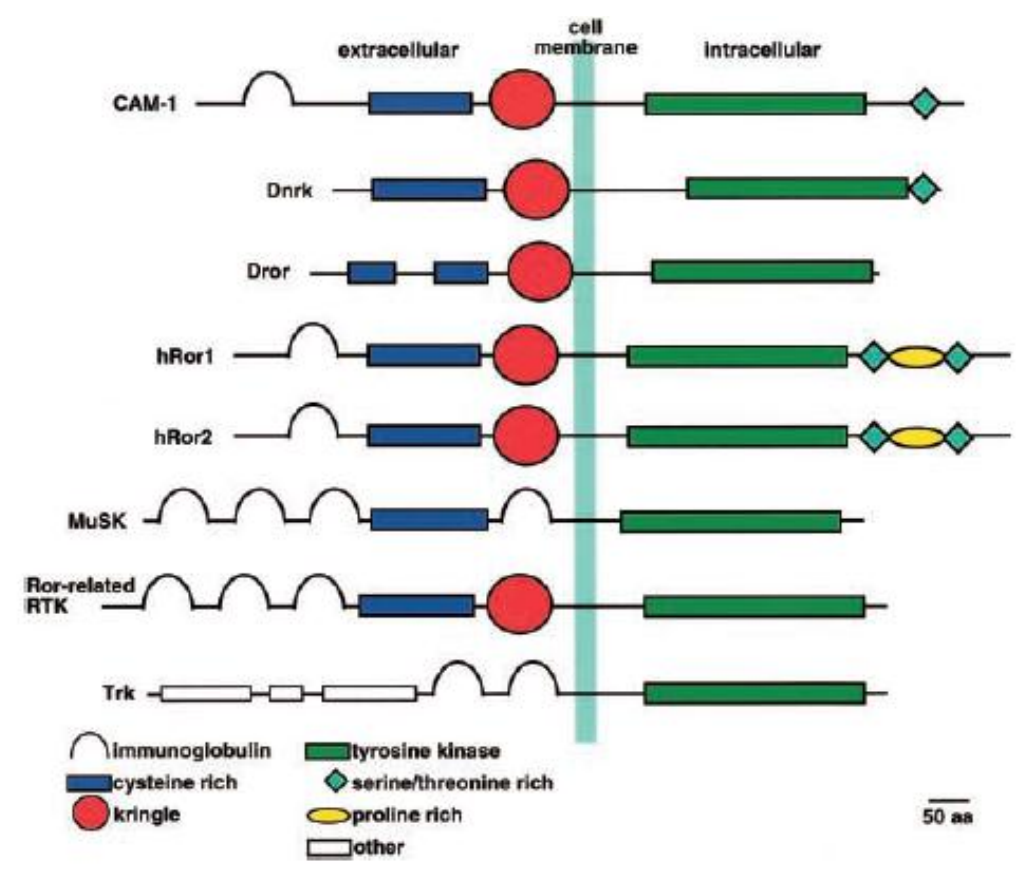

Figura 3: Representação esquemática da proteína ROR2 e comparação da conservação de domínios em ortólogos já encontrados. Adaptado de Forrester e cols., 2002.

A estrutura da proteína ROR2 está bem descrita, seus domínios exercem funções já conhecidas em outros receptores tirosina quinase que participam de vias de transdução de sinais. O que a diferencia é sua participação na regulação de células envolvidas no desenvolvimento esquelético. A atividade normal desencadeia via de sinalização intracelular levando informações ate o núcleo controlando assim expressão e produção de proteínas. Alterações em determinados domínios podem levar a perda da 
função normal da proteína ou ainda uma atividade parcial prejudicando as vias onde elas atuam (Yan e cols., 2008).

\section{I.4 Etiologia da Forma Autossômica Dominante}

Os primeiros estudos em modelo animal mostraram que camundongos nulos para Wnt5a e Ror2 exibiam fenótipos semelhantes aos encontrados em pacientes com síndrome de Robinow, incluindo dismorfismo facial, hipoplasia genital, encurtamento de membros e defeitos cardíacos e ainda, que a sinalização não canônica de Wnt que regulava a direção de migração celular era necessária para fusão do palato secundário durante o desenvolvimento embrionário (He e cols., 2008).

A partir dos resultados obtidos em modelo animal foi sugerido que as alterações no gene WNT5A poderiam estar envolvidas com o fenótipo apresentado pelos pacientes com a síndrome de Robinow. Buscando a confirmação dessa possível relação, em 2010 Person e cols, realizam um trabalho com pacientes diagnosticados com a forma dominante da síndrome e identificam mutações no gene WNT5A em $12 \%$ dos pacientes investigados, inclusive na família originalmente descrita por Robinow e cols. em 1969, confirmando o papel do gene WNT5A na etiologia da síndrome.

Outras três famílias com mutação em WNT5A foram descritas por Roifman e cols em 2014. Em uma das famílias a mutação foi identificada por sequenciamento de exoma e a mutação confirmada por sequenciamento Sanger. O gene WNT5A está localizado no braço curto do cromossomo 3, 3p21-p14, nas posições $\quad 55.465 .714$ - 55.505 .260 pares de base. Faz parte da família dos genes Wnt, que codificam proteínas de sinalização com atividade de regulação dos eventos morfogênicos, padronização durante a 
embriogênese, diferenciação celular, crescimento, migração e oncogênese (Oishi e cols., 2003).

Sua atividade de sinalização intracelular ocorre a partir do complexo receptorligante com os receptores FZD5 (frizzled-5) e ROR2 (receptor órfão com atividade tirosina quinase 2). O receptor ROR2 está envolvido com o fenótipo encontrado em pacientes na forma recessiva, as proteínas Wnt ligam-se diretamente no domínio rico em cisteína extracelular do receptor ROR2; essa interação entre o receptor e as proteínas Wnt desencadeia uma de via de transdução de sinal que tem atividade no desenvolvimento craniofacial e esqueleto (Roel e cols., 2005).

White e cols e Bunn e cols 2015 relataram oito e três pacientes respectivamente com a forma autossômica dominante da síndrome com mutações em DVL1 (dishevelled segment polarity protein 1), um gene que codifica um dos três ortólogos humanos da proteína da Dishevelled da Drosophila (DSH). DVL1 codifica uma fosfoproteína citoplasmática que regula a proliferação celular, atuando em processos de desenvolvimento, incluindo a segmentação e especificação de neuroblastos. A identificação de mutações nesse gene apoia o conceito de que mutações em outros genes da via WNT5A-ROR2 podem causar a Síndrome de Robinow.

Quanto à observação das manifestações clínicas, o fenótipo dos indivíduos com mutações DVL1 é concordante com as descrições clínicas anteriores como características faciais típicas, anomalias dentárias e mesomelia observadas em $100 \%$ dos indivíduos. Em contraste com os indivíduos com mutações WNT5A relatados até o momento com estatura normal e apenas $75 \%$ dos indivíduos com mutações em DVL1 apresentaram essa característica. Outro diferencial possível entre os dois tipos de DRS é macrocefalia observada em $100 \%$ dos indivíduos com mutações DVL1 presentes 
nestudo. Em alguns pacientes com mutação em $D V L 1$ foi observada osteoesclerose (White e cols e Bunn e cols 2015).

Estudos complementares são necessários para investigar se mutações no exon 14 do gene DVL1 têm uma atividade residual que compete com a proteína selvagem e sua função ou se o domínio C-terminal realiza um novo papel biológico imprevisível. O ganho de função da proteína mutante está previsto para contribuir para o traço de doença dominante. Mutações que geram perda de função observadas em camundongos nocaute para o gene $D v l l$, originam um fenótipo relativamente leve consistindo de problemas comportamentais e contrastam com os defeitos morfológicos graves observados em camundongos nocaute com mutações em Wnt5a ou Ror2. Estas observações em camundongos suportam a hipótese de que o DVL1 truncado em indivíduos com DRS não levam ao fenótipo por perda de função, mas, sim pelo ganho de função apenas no Exon 14 do gene DVL1 (White e cols., 2015).

\section{I.5 Interação funcional das proteínas WNTs com o receptor ROR2}

Wnts são proteínas que tem grande potencial devido à multiplicidade de processos de sinalização que estão envolvidas interferindo no desenvolvimento, formação do eixo embrionário primário, melanoma e doenças neurodegenerativas (Polakis e cols., 2012), a rede de sinalização Wnts é complexa e contém numerosos componentes. Os receptores que realizam interações com as proteínas wnts são Frizzled9, receptor de lipoproteína 6 (LRP6), ROR2, proteína Tyr quinase 7 (PTK7), receptor de quinase Tyr (RYK), cada receptor atuando em uma via de sinalização diferente (Yasuhiro e cols., 2010).

O receptor ROR2 funciona com atividade de regulação da sinalização de Wnts que associa-se pelo domínio citoplasmático rico em cisteína do receptor ROR2. Essa 
capacidade de regular a sinalização de Wnts em células osteoblásticas indica que o ROR2 pode regular a formação óssea. Existem 19 genes que codificam Wnts que ativam duas vias de sinalização que são classificadas em canônica ( $\beta$-cateninadependente) ou não-canônica ( $\beta$-catenina independente), a atividade de Wnts depende do contexto celular e da combinação do conjunto receptor e Wnt que realizam interação naquele momento por isso a variedade de combinações gera a complexidade das vias de sinalização (Ben e cols., 2009).

A melhor caracterização da via independente de $\beta$-catenina é a via de PCP (polaridade celular planar), mediada por receptores ROR2 que realizam interação com as proteínas wnts desencadeando processos de transcrição. O funcionamento dessa via é fundamental na osteoblastogênese e osteoclastogênese. (Kazuhiro e cols., 2013) ressaltam que o efeito de Wnt5a na osteoclastogênese foi abolido em culturas de células Ror2 - / - o que indica que os sinais mediados por Ror2 são cruciais para o efeito de Wnt5a na osteoclastogênese. Sugere-se então que a interação da proteína wnt com o receptor Ror2 possa desencadear a via PCP interferindo na diferenciação dos osteoblastos (Kazuhiro e cols., 2013). 


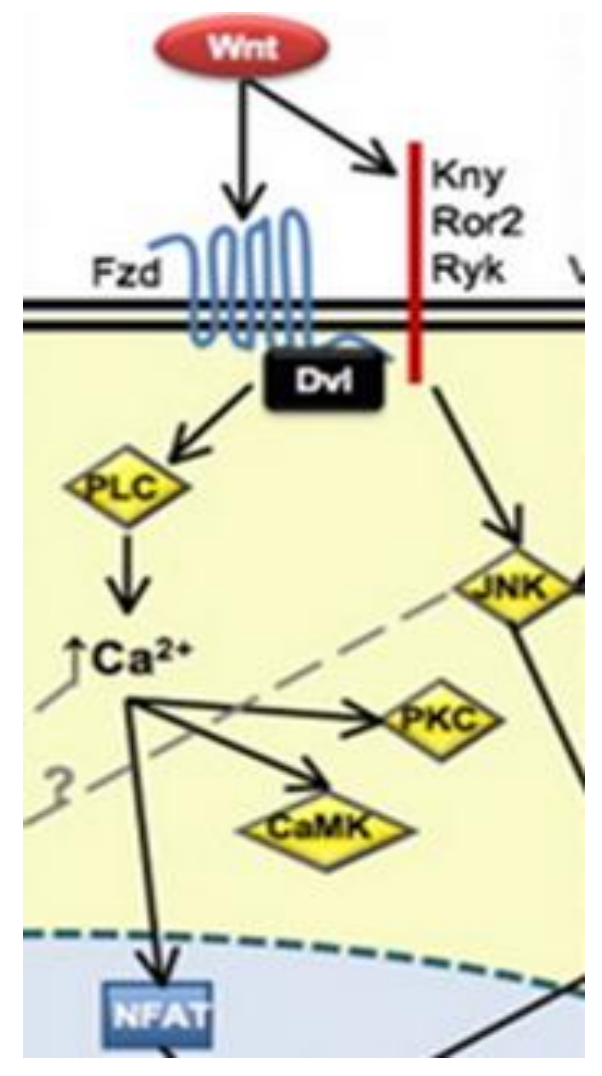

Figura 4: Representação esquemática da ligação do receptor Ror2 à proteína Wnt5a e complexo proteico DVL e a possível via de sinalização PCP (polaridade celular planar) não canônica. Adaptado de Kazuhiro e cols., 2013.

A atuação do receptor ROR2 na osteogênese e osteoclastogênese, mostra sua grande interferência no desenvolvimento do esqueleto. Falhas na sua atividade podem afetar a formação normal das estruturas ósseas, como encontrado nos pacientes com a síndrome de Robinow, forma autossômica recessiva. O conhecimento das mutações no gene ROR2 e o fenótipo associado podem colaborar para o entendimento do papel do receptor ROR2 na formação óssea e outros processos biológicos (Billiard e cols., 2006).

O diagnóstico molecular de pacientes com SR é fundamental para a melhor compreensão da fisiopatologia de cada uma das formas da síndrome, correlação entre o genótipo e o fenótipo dos indivíduos, bem como para a melhor compreensão dos mecanismos intracelulares e como as alterações nas proteínas podem interferir na regulação de sinalização Wnts. 


\section{Objetivo geral}

O objetivo geral desse trabalho foi identificar novas mutações no gene $R O R 2 \mathrm{em}$ pacientes com a Síndrome de Robinow autossômica recessiva.

\section{II.1 Objetivos Específicos}

1. Descrever detalhadamente a história familiar e o quadro clínico dos pacientes a fim de corroborar a hipótese diagnóstica da forma autossômica recessiva da síndrome

2. Identificar mutações no gene $R O R 2$ nos afetados

3. Verificar se há correlação entre o fenótipo e o tipo de mutação identificada. 


\section{Materiais e Métodos}

\section{III.1 Seleção dos pacientes para estudo}

1. Foram selecionados 11 pacientes com características clínicas da Síndrome de Robinow autossômica recessiva que aceitaram participar da pesquisa.

2. Os pacientes foram atendidos no Serviço de Genética Clínica do Hospital Universitário da Universidade de Brasília, no Centro de Estudos do Genoma Humano na Universidade de São Paulo ou encaminhados pela Robinow Syndrome Foundation, EUA.

3. Os pacientes ou genitores preencheram termo de consentimento livre e esclarecido.

4. O projeto foi aprovado pelo comitê de ética em pesquisa da Faculdade de Medicina da Universidade de Brasília (CEP FM: 079/2009; 25/11/2009).

\section{III.2 Material biológico}

As amostras de sangue foram obtidas por punção venosa, em tubos de coleta com sistema a vácuo e EDTA como anticoagulante. Apenas um paciente teve amostra de saliva coletada. Os voluntários maiores de 18 anos assinaram o termo de consentimento livre e esclarecido, os pacientes menores de idade tiveram o consentimento livre e esclarecido assinado pelos responsáveis. 


\section{III.3 Triagem de mutações no gene ROR2.}

A pesquisa de mutações no gene foi realizada por sequenciamento Sanger direto em cinco pacientes. Em seis pacientes o sequenciamento das regiões codificantes do gene ROR2 foi realizado utilizando a plataforma Ion Torrent PGM. Apenas em um paciente foi realizado MLPA para detecção de alterações.

\section{III.3.1 Extração de DNA}

A extração de DNA foi feita a partir do sangue periférico pelo método Puregene "Salting out". Este método é dividido em etapas, sendo a primeira de lise celular, onde foi utilizado 5mM MgCl2, 1mM EDTA pH 8,0 em uma reação e, 10mM Tris pH 7,5, $1 \mathrm{mM}$ EDTA pH 8,0 e 1\% SDS em outra, para cada reação a solução foi centrifugada a $3400 \mathrm{rpm}$ por 10 minutos. Para a segunda etapa utilizou-se $1 \mathrm{ml}$ da solução de precipitação de proteína ao lisado celular. Esta solução contém 7,5M de NH4 Ac. Centrifugou-se a $3400 \mathrm{rpm}$ por 10 minutos. As proteínas precipitadas formam um pellet marrom escuro e compacto.

Na etapa de precipitação de DNA, o sobrenadante foi transferido para um tubo falcon contendo $3 \mathrm{ml}$ de isopropanol. O tubo foi invertido lentamente até que se formasse um novelo de DNA. A reação foi centrifugada a $3400 \mathrm{rpm}$ por 3 minutos. Retirou-se o sobrenadante, e adicionou-se $3 \mathrm{ml}$ de etanol absoluto. A reação foi novamente centrifugada. Depois disso, drenou-se o tubo e deixou-se o DNA secar a temperatura ambiente por 15 minutos. Na última etapa, acrescentou-se ao tubo com o DNA 200-250 $\mu 1$ de TE 1x ou água milliQ, que resultou em uma concentração aproximada de $400 \mathrm{ng} / \mu \mathrm{l}$. O DNA foi armazenado a $2-8^{\circ} \mathrm{C}$. O DNA obtido foi quantificado no espectrofotômetro Nanodrop (Thermo Scientific). 


\section{III.3.2 PCR- Reação em cadeia pela polimerase}

Para as reações de PCR, num volume total de $25 \mu$, foram utilizados $80-200$ ng de DNA genômico, 2,5 $\mu \mathrm{l}$ de dNTP $(200 \mu \mathrm{M}$ de dCTP, dTTP, dGTP e dATP); 2,5U da enzima Taq polimerase (Invitrogen, Carlsbad, USA) e 2,5 $\mu$ l de tampão específico dessa enzima; $\mathrm{MgCl} 2$ em concentração otimizada para cada par de primer, $1 \mu \mathrm{l}(1,5 \mu \mathrm{M})$, de pares de primers específicos na tabela 1 e quantidade complementar de água. As condições de amplificação foram as seguintes: cinco minutos de desnaturação inicial a $94^{\circ} \mathrm{C}, 35$ ciclos de um minuto a $94^{\circ} \mathrm{C}$, um minuto à temperatura de annealing calculada para cada par de primer e um minuto a $72^{\circ} \mathrm{C}$, seguidos de uma etapa de extensão de 10 minutos a $72^{\circ} \mathrm{C}$. 
Tabela 1: Primers utilizados para amplificação da região codificante do gene ROR2.

Cada par de primer amplifica um exon do gene ROR2 ou parte dele.

\begin{tabular}{|c|c|}
\hline Exon & Sequência \\
\hline $1 \mathrm{~F}$ & 5'-TGTAAAACGACGGCCAGTCCTTTGTGTTCAAGCGTTCC- 3' \\
\hline $1 \mathrm{R}$ & 5'-CAGGAAACAGCTATGACCCCTCGTTCAGGAGCATGG- 3' \\
\hline $2 \mathrm{~F}$ & 5'-TGTAAAACGACGGCCAGTCCGCATTTGCTATTCTTGTG- 3' \\
\hline $2 \mathrm{R}$ & 5'-CAGGAAACAGCTATGACCATGCCCTCCAAGTCAAGAAA- 3' \\
\hline $3 F$ & 5'-TGTAAAACGACGGCCAGTAAATCGAAACCTTCCCTTGG- 3' \\
\hline $3 R$ & 5'-CAGGAAACAGCTATGACCTGCTGACTGGTGTGTGTTCA- 3' \\
\hline $4 \mathrm{~F}$ & 5'-TGTAAAACGACGGCCAGTAATCACGAGTGGAGCCTGAG- 3' \\
\hline $4 \mathrm{R}$ & 5'-CAGGAAACAGCTATGACCCCCAGCCAACTTCTAGCAAA- 3' \\
\hline $5 \mathrm{~F}$ & 5'-TGTAAAACGACGGCCAGTCAGGTTTTTGTGTGACTTATGTG- 3' \\
\hline $5 \mathrm{R}$ & 5'-CAGGAAACAGCTATGACCGGCCAGGAACATTTTTAGGG- 3' \\
\hline $6 \mathrm{~F}$ & 5'-TGTAAAACGACGGCCAGTAGTGGGCAGTCTGGGATG- 3' \\
\hline $6 \mathrm{R}$ & 5'-CAGGAAACAGCTATGACCCCCCCATACACATTTCAAGG- 3' \\
\hline $7 \mathrm{~F}$ & 5'-TGTAAAACGACGGCCAGTGTGGGCTTGGGACTTCATTA- 3' \\
\hline 7R & 5'-CAGGAAACAGCTATGACCCCAACCCAGGTCAGGACA- 3' \\
\hline $8 \mathrm{~F}$ & 5'-TGTAAAACGACGGCCAGTTGAAGATTTTGGCTGGAGGT- 3' \\
\hline $8 \mathrm{R}$ & 5'-CAGGAAACAGCTATGACCCATTTAATGTTGGGGGAAACA- 3' \\
\hline $9-1 F$ & 5'-TGTAAAACGACGGCCAGTGCACAGGGACTCCACTCCT- 3' \\
\hline $9-1 R$ & 5'-CAGGAAACAGCTATGACCCCACAAGGTGCACGAAGTC- 3' \\
\hline $9-2 \mathrm{~F}$ & 5'-TGTAAAACGACGGCCAGTAGCCCCTGAGCATGATCTTC- 3' \\
\hline $9-2 R$ & 5'-CAGGAAACAGCTATGACCGGATCATCTCCACCACATCC- 3' \\
\hline $9-3 F$ & 5'-TGTAAAACGACGGCCAGTGTCCTACGGTGTGGTCCTGT- 3' \\
\hline $9-3 R$ & 5'-CAGGAAACAGCTATGACCTAGAAGTTGGGCAGGTAGGC- 3' \\
\hline $9-4 \mathrm{~F}$ & 5'-TGTAAAACGACGGCCAGTCATGAAGGGCCAGATCAGA- 3' \\
\hline $9-4 R$ & 5'-CAGGAAACAGCTATGACCAGTCTGCAAACAAGCCCACT- 3' \\
\hline
\end{tabular}


O resultado da amplificação por PCR foi verificado por meio de eletroforese em gel de agarose a 2,0\%, coloração com brometo de etídio $(0,5 \mu \mathrm{g} / \mathrm{ml})$ e visualização sob luz ultra-violeta.

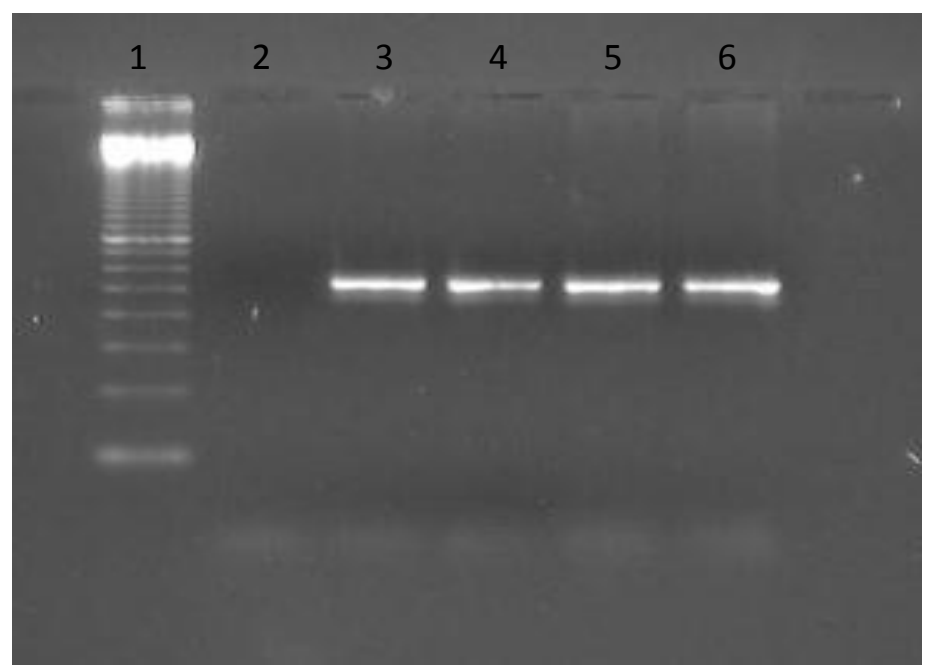

Figura 5: Resultado da amplificação do exon 2 do gene ROR2. 1- Marcador de peso molecular, 2- Controle negativo, 3-6 Amostras de pacientes

\section{III.3.3 Sequenciamento Sanger}

A purificação das amostras para sequenciamento foi realizada com kit Illustra ${ }^{\mathrm{TM}}$ ExoProStar ${ }^{\mathrm{TM}}$.

O sequenciamento Sanger foi realizado para cinco dos onze pacientes participantes da pesquisa. Para o sequenciamento Sanger foi utilizado o sequenciador ABI 3130XL da Applied Biosystems, no Laboratório de Biotecnologia do Programa de Pós-graduação em Ciências Genômicas e Biotecnologia da Universidade Católica de Brasília, seguindo o protocolo de sequenciamento de rotina do laboratório. 


\section{III.3.4 Ion Torrent ${ }^{\mathrm{TM}}$ PGMTM}

O sequenciamento do gene foi realizado utilizando a plataforma "Ion Torrent PGM TM" para seis dos onze pacientes participantes da pesquisa. O protocolo foi realizado segundo instruções do fabricante com resumido a seguir:

\section{Etapas}

1. Preparação da biblioteca

2. Emulsão

3. Enriquecimento

4. Controle de qualidade

5. Sequenciamento

\section{Preparação da biblioteca}

Para preparo da biblioteca as amostras foram quantificadas no Qubit e Nanodrop e diluídas para $10 \mathrm{ng} / \mu \mathrm{L}$. A seleção dos segmentos sequenciados foi feita com o Ion Ampliseq Inherited Disease Panel (Life Technologies), que inclui o gene ROR2. Foram preparados 3 pools de primers para cada amostra totalizando $10 \mu \mathrm{L}$. Logo depois do preparo as amostras passaram pelo termociclador, para amplificação. Os três tubos contendo pools de primers com amostras de cada paciente foram unidos em um só para digestão. As beads foram adicionadas as amostras. Realizou-se então a purificação das bibliotecas com etanol 70\%, e a equalização da biblioteca com o Ion Library Equalizer Kit. 


\section{Purificação da biblioteca}

\section{*Primeiro estágio de purificação}

A reação foi transferida para um tubo $1,5 \mathrm{~mL}$, foram adicionadas $25 \mu \mathrm{L}$ de beads Agencourt AMPure XP; incubadas durante 5 min em temperatura ambiente; os tubos foram colocados na rack magnética e incubados por $5 \mathrm{~min}$; o sobrenadante foi removido para um novo tubo de $1,5 \mathrm{~mL}$, sem perturbar o pellet.

\section{*Segundo estágio de purificação}

Foram adicionadas $60 \mu \mathrm{L}$ de beads; incubadas durante 5 min em temperatura ambiente; os tubos foram colocados na rack magnética e incubados por 5 min; o sobrenadante foi descartado sem perturbar o pellet; logo depois foram adicionados 300 $\mu \mathrm{L}$ de etanol 70 o sobrenadante foi descartado sem perturbar o pellet; a lavagem com etanol $70 \%$ foi repetida e o sobrenadante descartado; os tubos foram removidos da rack magnética e foram adicionados $50 \mu \mathrm{L}$ de TE, eluindo o pellet com a solução; os tubos foram colocados na rack magnética e incubados por $5 \mathrm{~min}$; a solução foi transferida para novo tubo de PCR $0.2 \mathrm{~mL}$; foram retirados $10 \mu \mathrm{L}$ para quantificar no Qubit.

\section{Emulsão}

Foi realizada de acordo com o documento "Ion PGM Template OT2 200 Kit User

\section{Guide".}




\section{Enriquecimento}

\section{*Preparo da corrida}

Uma solução com $280 \mu \mathrm{L}$ de Tween Solution e $40 \mu \mathrm{L}$ de $\mathrm{NaOH}$, totalizando 320 $\mu \mathrm{L}$ foi preparada. Vortexada por 30 seg e centrifugada por 2 seg. Foram retirados $13 \mu \mathrm{L}$ para um tubo 1,5 mL, adicionados $130 \mu \mathrm{L}$ de My One Beads Wash Solution, posteriormente vortexada e centrifugada novamente. O tubo foi colocado na rack magnética e incubado por 2 min. $\mathrm{O}$ sobrenadante foi removido e descartado. $\mathrm{O}$ procedimento de lavagem com $130 \mu \mathrm{L}$ de MyOne Beads Wash Solution foi repetido. O sobrenadante foi removido e130 $\mu \mathrm{L}$ de MyOne Beads Wash foram adicionados Solution. O tubo foi retirado da rack magnética, vortexado por 30 seg e centrifugado brevemente por 2 seg. Foi adicionado $10 \mu \mathrm{L}$ de Neutralization Solution em um tubo de PCR.

\section{*Lavagem}

A tira de 8 poços foi preparada, foram pipetados $100 \mu \mathrm{L}$ da solução que foi transferida para o poço 1 da tira. A solução MyOne Beads $130 \mu \mathrm{L}$ foi colocadano poço 2 da tira. Nos poços 3, 4 e 5 da tira pipetamos $300 \mu \mathrm{L}$ de Ion One Touch Wash Solution. Os poços 6 e 8 ficaram vazios e no poço 7 pipetamos $300 \mu \mathrm{L}$ da solução Melt-Off. O tubo de PCR de 0,2 $\mathrm{mL}$ foi adicionado com os $10 \mu \mathrm{L}$ de Neutralization Solution no orifício próximo ao braço mecânico do equipamento. Posteriormente foi realizada a lavagem da amostra no equipamento. 


\section{Controle de Qualidade}

Para o controle de qualidade foram adicionados $19 \mu \mathrm{L}$ de Annealing Buffer e 1 $\mu \mathrm{L}$ de Ion Probes ao tubo de PCR com $2 \mu \mathrm{L}$ da amostra. Levados ao termociclador ,após a termociclagem, foram adicionados $200 \mu \mathrm{L}$ do Quality Control Wash Buffer centrifugado por 1,5 minutos. O sobrenadante foi retirado sem perturbar o pellet deixando $10 \mu \mathrm{L}$. A lavagem com $200 \mu \mathrm{L}$ de wash buffer e centrifugação por mais 2 vezes, sempre deixando o volume de $10 \mu \mathrm{L}$, foi repetida totalizando 3 lavagens. Depois da lavagem final, foi adicionado $190 \mu \mathrm{L}$ do Quality Control Wash Buffer para um volume final de $200 \mu \mathrm{L}$. O conteúdo foi transferido para um tubo do Qubit para realização da leitura.

\section{Sequenciamento}

A reação de sequencimaneto foi realizada seguindo os documentos "Ion PGM"M Sequencing 200 Kit v2” (Publication Number MAN0007360 e Publication Number MAN0007273). 


\section{III.3.5 MLPA}

Para a investigação de deleções ou duplicações nos genes candidatos utilizamos a técnica Multiplex Ligation-dependent Probe Amplification (MLPA). Essa técnica é um método simples, sensível, rápido e econômico que visa à quantificação relativa quanto ao número de cópias de até 50 sequências de ácidos nucléicos em um experimento.

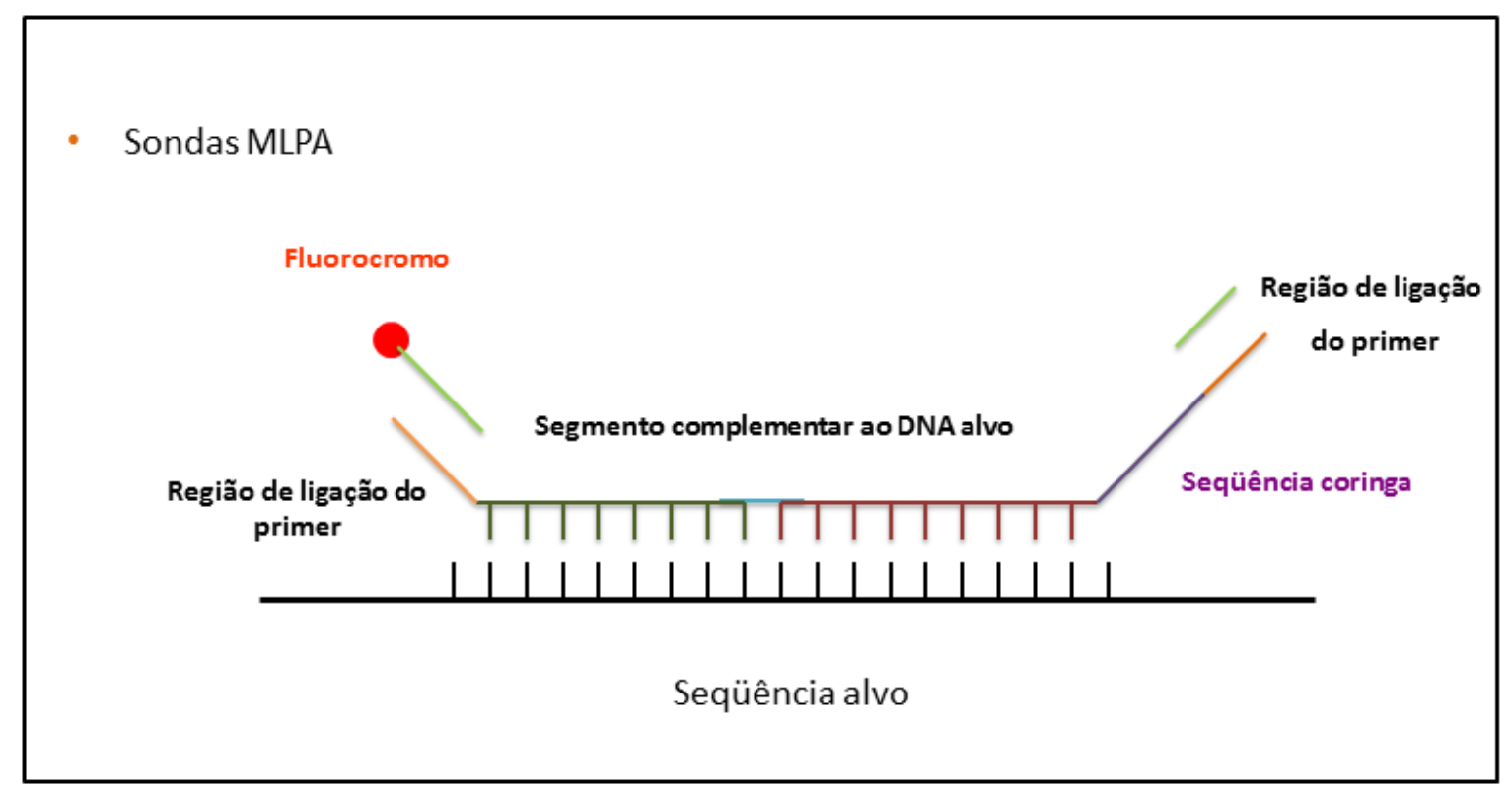

Figura 6: Análise de número de cópias do gene ROR2 por MLPA.

Para as reações de MLPA, selecionamos o kit P179 (Limb-1) que inclui sondas para o gene ROR2. A técnica MLPA permite a identificação do número de cópias de uma dada sequência de DNA por meio da hibridação de sondas específicas e amplificação por PCR. Essas sondas apresentam dois segmentos complementares às sequências-alvo de DNA: um oligonucleotídeo sintético curto e um oligonucleotídeo sintético longo. Este contém uma sequência stuffer que varia de tamanho nas diferentes sondas, permitindo a separação dos diferentes fragmentos por eletroforese capilar. Cada kit é composto de até 50 pares de sondas permitindo assim a análise de diversas regiões 
simultaneamente. Inicialmente as sondas são hibridizadas ao DNA e em seguida os fragmentos são ligados por uma ligase. Após uma nova desnaturação o fragmento formado pela junção das sondas é amplificado por PCR. A reação de PCR é realizada com um único par de primers, comum a todas as sondas. Foram seguidos todos os passos e quantidades sugeridas pelo fabricante.

*Condições de hibridação e amplificação: $5 \mu \mathrm{L}$ de DNA (50-100ng) foram colocados em microtubos e levados ao termociclador para desnaturação por 10 min a $98^{\circ} \mathrm{C}$. À temperatura ambiente foi adicionado o mix de hibridação contendo por reação $1,5 \mu \mathrm{L}$ de MLPA buffer e $1,5 \mu \mathrm{L}$ de SALSA probe mix, seguindo-se desnaturação a $95{ }^{\circ} \mathrm{C}$ por 1 min e hibridação overnight a $60^{\circ} \mathrm{C}$ (entre 16-20h).

Após a hibridação foi adicionado o mix de ligação contendo $25 \mu \mathrm{L}$ de $\mathrm{H}_{2} \mathrm{O}, 3 \mu \mathrm{L}$ de Ligase Buffer A, $3 \mu \mathrm{L}$ de Ligase Buffer B e $1 \mu \mathrm{L}$ de enzima Ligase-65. Os tubos foram incubados por $15 \mathrm{~min}$ a $54^{\circ} \mathrm{C}$ e $5 \mathrm{~min}$ a $98^{\circ} \mathrm{C}$. Em seguida foi realizada a amplificação por PCR. Para o volume final de $50 \mu \mathrm{L}$, foram misturados $7,5 \mu \mathrm{L}$ de $\mathrm{H}_{2} \mathrm{O}, 2 \mu \mathrm{L}$ de SALSA PCR primer mix e $0,5 \mu \mathrm{L}$ de SALSA polymerase. As condições da amplificação foram: 35 ciclos de 30 seg a $95^{\circ} \mathrm{C}$, hibridação a $60^{\circ} \mathrm{C}$ por 30 seg e extensão de 30 seg a $72{ }^{\circ} \mathrm{C}$, seguidos de extensão final a $72{ }^{\circ} \mathrm{C}$ por 20 min. A reação de MLPA foi realizada em amostras teste (pacientes) e controle (individuos fenotipicamente normais).

Em seguida os fragmentos da PCR foram diluídos e misturados a $0,1 \mu \mathrm{L}$ de GS500 LIZ® (Applied Biosystems, EUA) e $9 \mu \mathrm{L}$ de Formamida Hi-Di (Applied Biosystems, EUA) e submetidos à eletroforese capilar. A análise do produto do MLPA foi feita em sequenciador automático ABI 3130 (Applied Biosystems).

O marcador de peso molecular GS500 LIZ (Applied Biosystems) foi utilizado para determinação do tamanho dos fragmentos e os resultados foram analisados utilizando-se os programas Genemapper (Applied Biosystems) e Coffalyser (MRC- 
Holland). A análise dos resultados foi feita calculando-se o valor da intensidade de amplificação da sonda específica à média das intensidades de amplificação de todas as sondas em relação à média de intensidade nas amostras controle. 


\section{Resultados e Discussão}

\section{IV.1 Descrição clínica}

\section{Paciente 1}

Paciente do sexo feminino com seis anos de idade, nascida na Índia, filha de pais não consanguíneos. Aos seis anos a estatura era de $90 \mathrm{~cm}\left(<3^{\circ}\right.$ percentil $)$ e o peso $14 \mathrm{~kg}(<$ $3^{\text {o }}$ percentil). Ao exame clinico observou-se baixa estatura, bossa frontal, hipertelorismo, ponte nasal deprimida. O nariz era curto com narinas antevertidas, hipertrofia gengival e a língua era bífida. As mãos e antebraços eram curtos, assim como os membros inferiores. Além disso as cabeças radiais eram deslocadas posteriormente em ambos os lados.

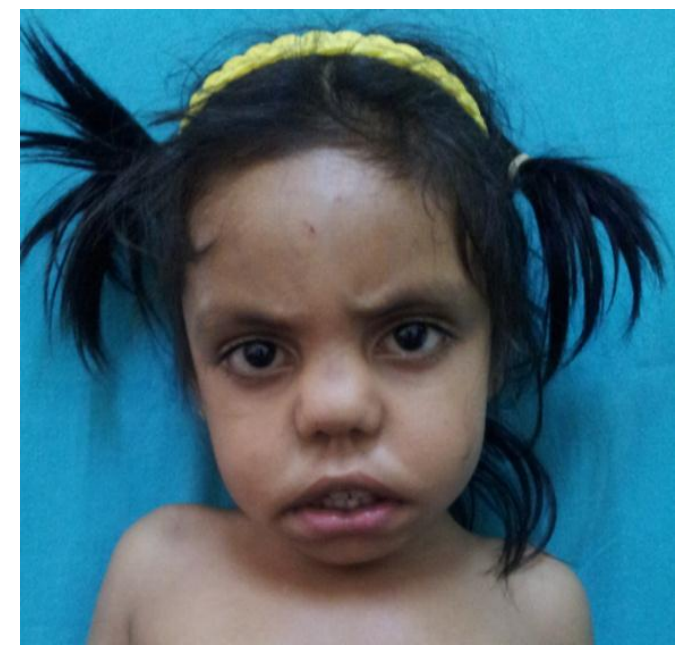

Figura 10: paciente 1 com seis anos origem étnica da Índia

\section{Testes Radiológicos}

Exame radiológico da coluna mostrou hemivértebras na espinha dorsal. Foi observado encurtamento acromesomélico com luxação bilateral simétrica. 


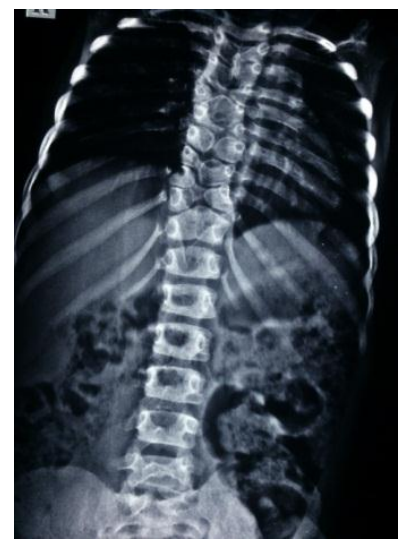

b

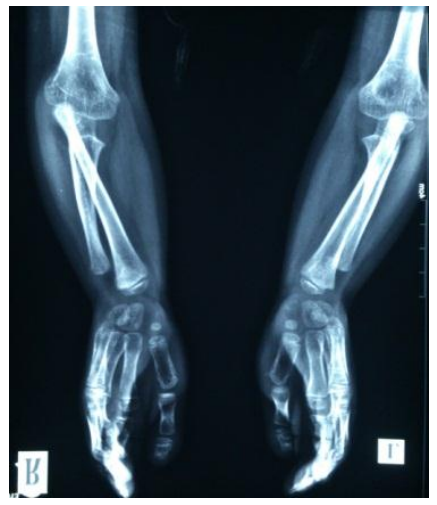

Figura 11: a/b Imagens radiológicas da paciente 1 aos seis anos de idade

\section{Paciente 2}

Paciente do sexo feminino filha de casal não consanguíneo, originária dos Estados Unidos. Ao exame clínico apresentou baixa estatura, hipertelorismo, cílios longos, narinas antevertidas, ponte nasal larga, boca triangular, lábio superior fino, hipoplasia gengival, braquidactilia, polegar alargado, clinodactilia e limitação da supinação dos cotovelos. A genitália era hipoplásica. O exame radiológico revelou fusão de costelas.

$\mathbf{a}$

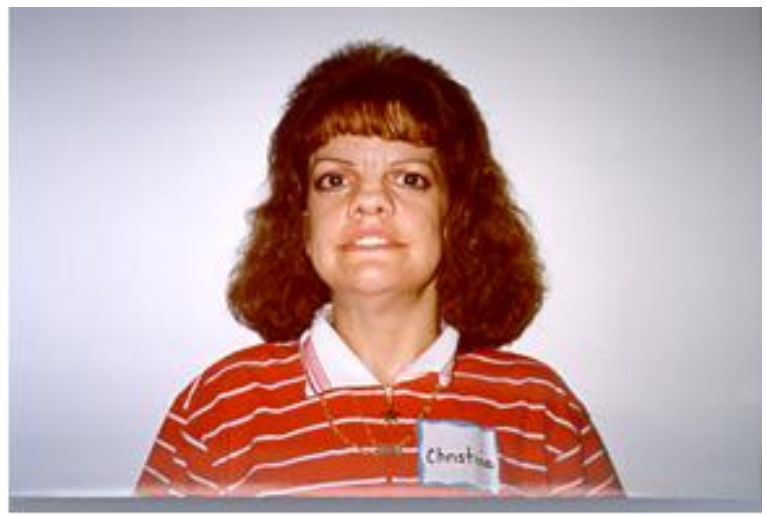

Figura 12: a/b Paciente 2 aos 39 anos de idade b

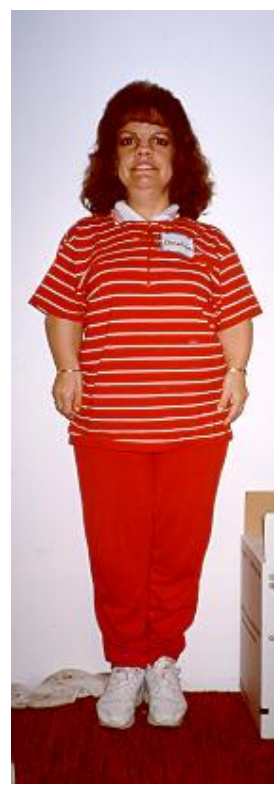




\section{Paciente 3}

Paciente brasileira do sexo feminino com três anos de idade filha de casal não consanguíneo. Ao exame clinico observou-se baixa estatura, bossa frontal, hipertelorismo, cílios longos, ponte nasal larga e baixa, narinas antevertidas, boca triangular, microretrognatia e pescoço curto. Os membros superiores eram curtos, as mãos pequenas com braquidactilia, clinodactilia e polegares alargados. Apresentava pectus exavatum e hipoplasia de pequenos lábios

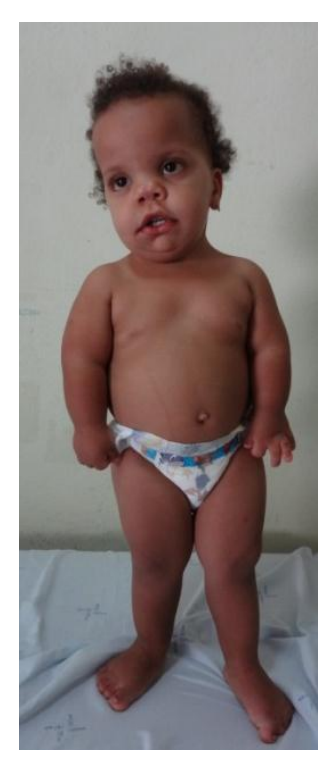

Figura 13: Paciente 3 aos três anos de idade

\section{Testes radiológicos}

Os exames radiológicos revelaram encurtamento de mesomélico, subluxação proximal do radio bilateral, hipoplasia de fêmur direito, múltiplas malformações de vertebras torácicas, caracterizadas por hemivertebras e vertebras em borboleta. Fusão de arcos costais proximais à esquerda, na região médio-torácica. 


\section{Paciente 4}

Paciente do sexo masculino, norte-americano, filho de pais não consangüíneos. Ao exame clínico apresentava: baixa estatura, bossa frontal, hipoplasia de face média, cílios longos, hipertelorismo (DII: $31 \mathrm{~mm}$, DIE: $93 \mathrm{~mm}$, ambas $>97^{\circ}$ percentil), nariz curto com narinas antevertidas, ponte nasal larga, filtro longo, boca triangular, cantos da boca voltados para baixo, lábio superior fino, língua bífida, hiperplasia de gengiva e microretrognatia. Tinha hipodontia. A genitália era hipoplasica com micropênis e hipospadia. Os membros tinham encurtamento mesomélico. As mãos tinham prega palmar transicional, braquidactilia, camptodactilia, clinodactilia de $2^{\text {os }}$ e $5^{\text {os }}$ dedos, membranas interdigitais Exames de raios-X revelaram fusão de costelas, hemivértebras e idade óssea atrasada.

$\mathbf{a}$

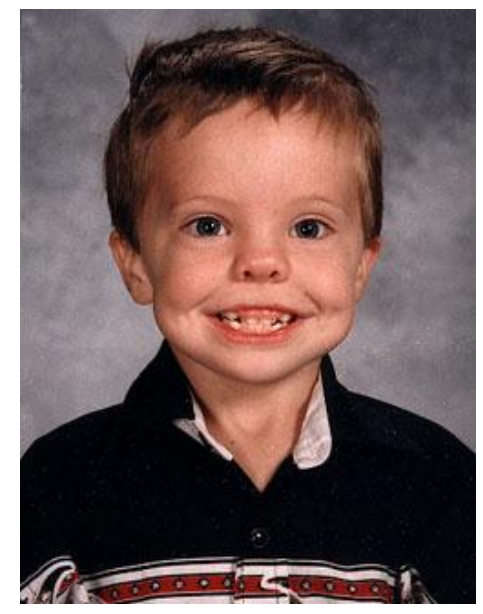

b

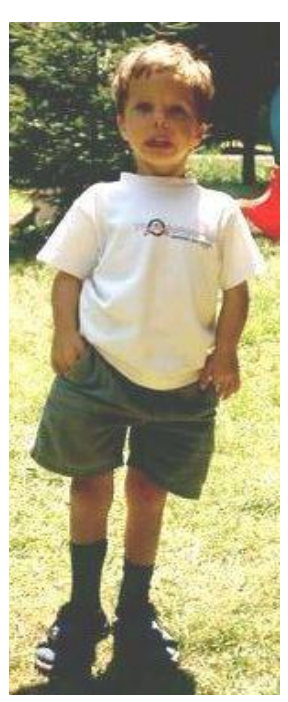

Figura 14: a/b Paciente 4 aos a) 4 anos b) 10 anos de idade 


\section{Testes radiológicos}

Exames de raios-X revelaram fusão de costelas, hemivértebras e idade óssea atrasada.

\section{Heredograma}

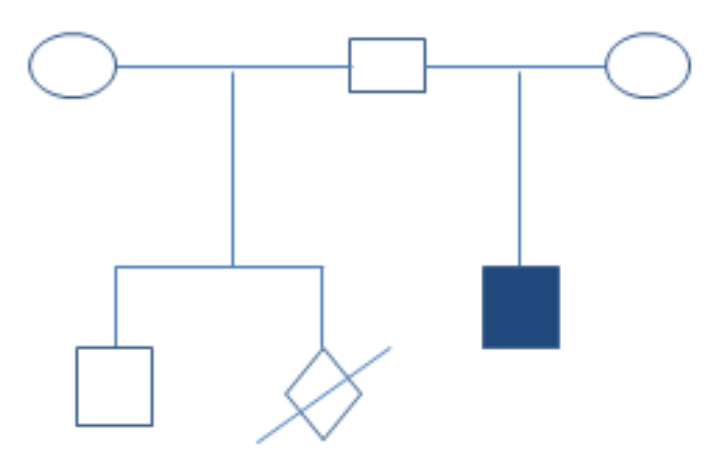

Figura 15: Heredograma do paciente 4

\section{Paciente 5}

Paciente originária da Turquia do sexo feminino, filha de um casal consanguíneo. Ao exame clínico observou-se baixa estatura, encurtamento de membros, fusão de costelas, hemivértebras, hipertelorismo, nariz curto com narinas antevertidas, ponte nasal larga, ponte nasal larga, hipoplasia do terço médio da face, cantos da boca voltados para baixo, hiperplasia gengival, micrognatia, língua bífida, braquidactilia, pectus excavatum e pequenos lábios hipoplásicos. Não foi possível obter imagens da paciente.

\section{Paciente 6}

Paciente brasileiro do sexo masculino, atualmente com 18 anos de idade, filho de casal consanguíneo. No exame clínico notou-se baixa estatura, macrocefalia, hipertelorismo, cílios longos, hipoplasia de face média, raiz nasal alargada e plana, ponta do nariz 
quadrada, narinas antevertidas, micrognatia, hipertrofia gengival, palato alto, ponta da língua bífida, orelhas de implantação baixa. A genitália era hipoplásica.

$\mathbf{a}$

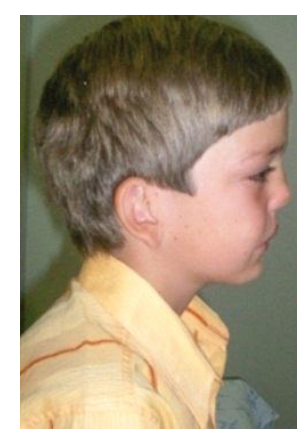

b

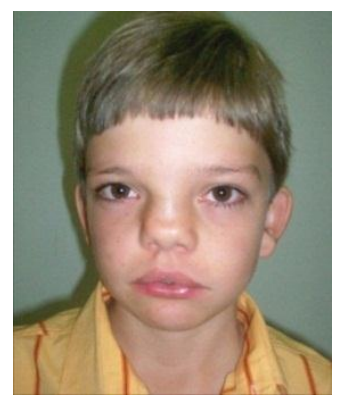

Figura 16: a/b paciente 12 aos anos de idade

a

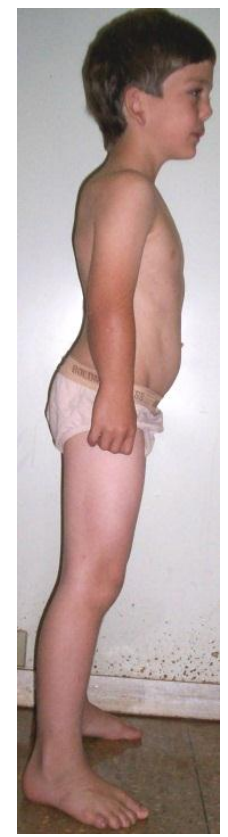

b

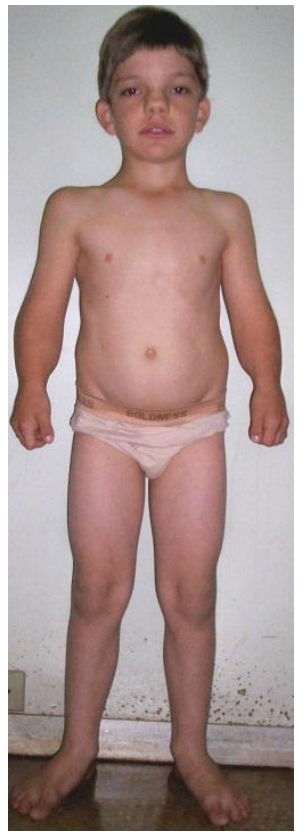

Figura 17: a/b paciente 12 aos anos de idade 


\section{Estudo Radiológico}

Presença de deformidades na coluna dorsal, caracterizada pela presença de hemivertebras. Rádio e ulnas se mostraram encurtados e de espessura aumentada. Nas mãos se observou metacarpianos e falanges curtas (braquidactilia).

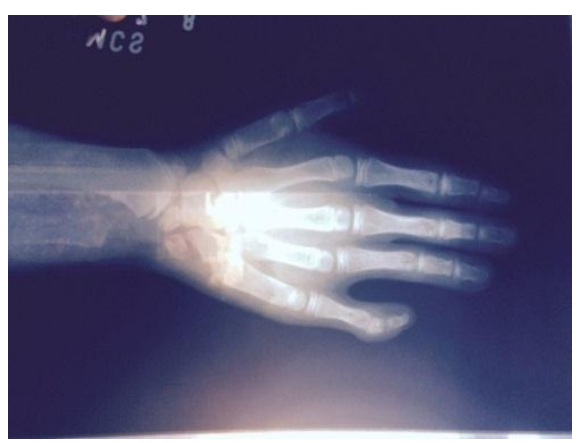

Figura 18: raio x rádio e ulna encurtados

$\mathbf{a}$

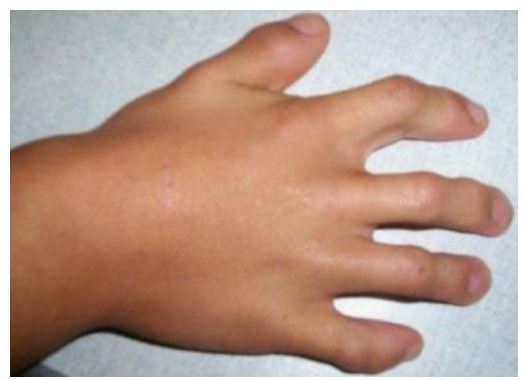

b

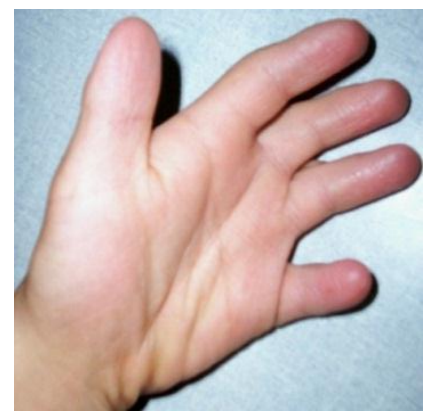

Figura 19: a/b metacarpianos e falanges curtas 


\section{Heredograma do paciente 6}

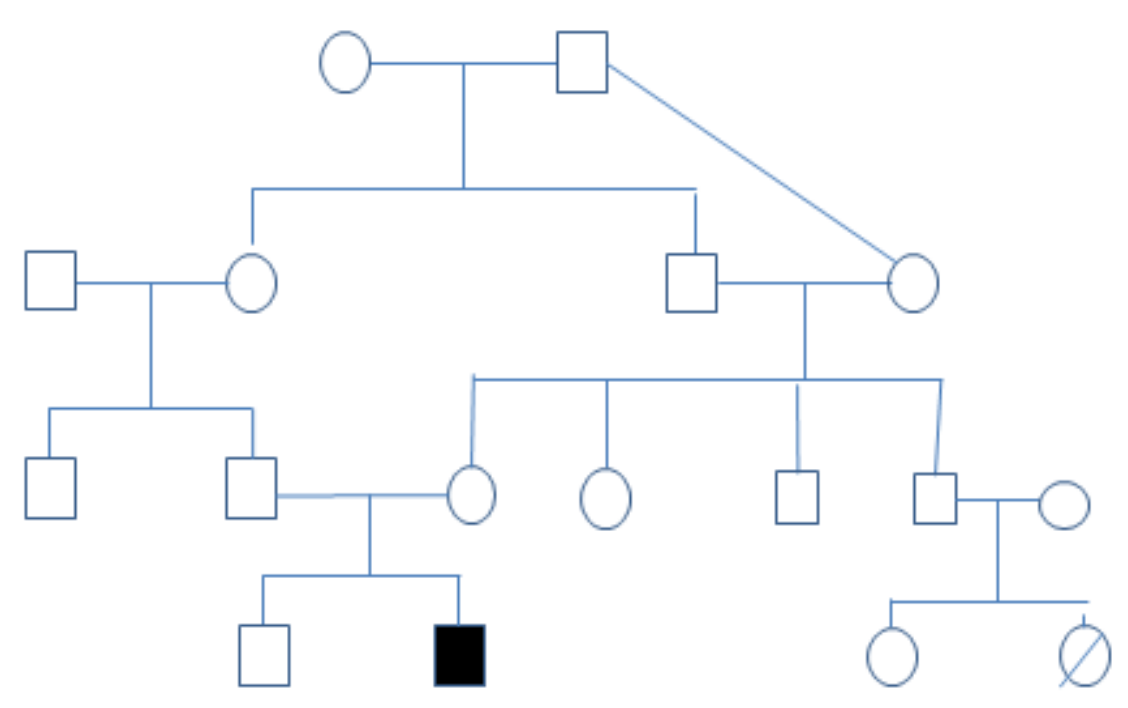

Fugura 20: Heredograma do paciente 6

\section{Paciente 7}

Paciente brasileira, filha de casal não consangüíneo, proveniente de mesma cidade do interior de Minas Gerais. Possuem oito irmãos normais e um irmão também afetado pela SRR. Ao exame clínico realizado aos 7 anos de idade a paciente apresentava: baixa estatura, fácies fetal, braquimesomelia, braquidactilia e hipoplasia de pequenos lábios. Seu irmão (13 anos) apresentava: macrocefalia, fronte ampla, hipertelorismo, cílios longos, nariz curto com ponta voltada para cima, narinas antevertidas, filtro longo, macrostomia, lábio inferior com fenda de linha média, língua bífida, micrognatia, encurtamento mesomélico de membros, braquidactilia, encurtamento de metacarpos, limitação do movimento de supinação dos cotovelos, unhas hipoplásicas, micropênis e criptorquidia. Os exames de raios $\mathrm{X}$ dos afetados revelaram encurtamento e deformidade rádio-ulnar bilateral, hemivértebras torácicas e fusão de costelas. Não conseguimos contatar a família para novo exame clínico, coleta de sangue e aconselhamento genético. O material biológico havia sido armazenado para estudos 
posteriores, com o consentimento dos responsáveis. O exame molecular foi realizado na amostra do irmão afetado
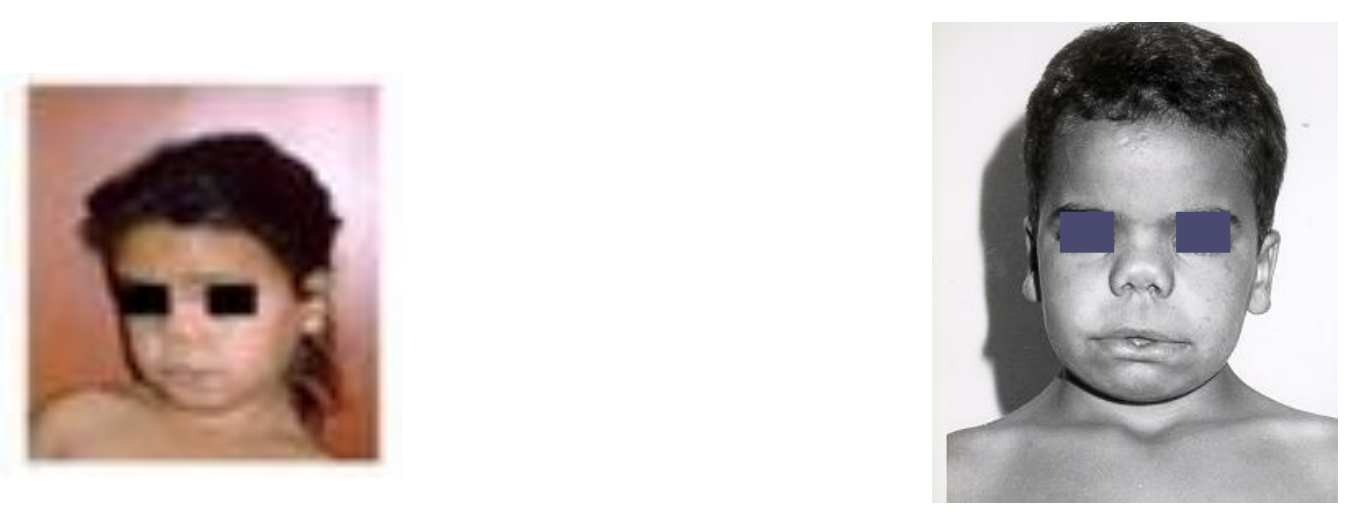

Figura 21: a/b a) Irmã do paciente 7 também afetada b) Paciente 7

\section{Heredograma}

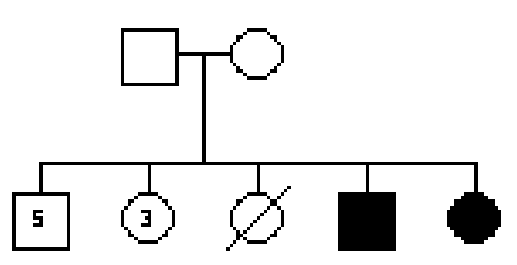

Figura 22: Heredograma do pacinte 7

\section{Paciente 8}

Paciente do sexo feminino, brasileira, filha de pais consangüíneos, sem outros casos na família. Foi encaminhada pelo Hospital de Reabilitação de Anomalias Crânio-faciais e examinada pela primeira vez no aos quatro anos de idade. Nasceu de parto cesáreo, pesando $3100 \mathrm{~g}\left(25^{\circ}\right.$ percentil $)$ e tinha $40 \mathrm{~cm}\left(<3^{\circ}\right.$ percentil $)$. Ao exame clínico notou-se: 
baixa estatura $\left(97 \mathrm{~cm},<3^{\circ}\right.$ percentil), hipoplasia de face média,pescoço curto, orelhas com rotação incompleta e de baixa implantação, hipertelorismo, epicanto, inclinação fissuras palpebrais oblico descendente, cílios longos, , ponte nasal larga e baixa, nariz bulboso, narinas antevertidas, boca triangular, lábio superior fino com arco de cupido acentuado,língua bífida, hiperplasia de gengiva, hipodontia (ausência de pré-molares superiores), má implantação dentária, retrognatia. Apresentava hipoplasia de clitóris e pequenos lábios. Ambas as mãos tinham prega palmar única, polegar alargado, ectrodactilia, sindactilia, braquidactilia e displasia de unhas. Os membros tinham encurtamento mesomélico. Os pés apresentavam hálux alargado e sindactilia cutânea do hálux e $2^{\circ}$ artelhos. Os mamilos eram hipoplásicos. Tinha pectus excavatum, escoliose, lordose e fusão de costelas.

a b c

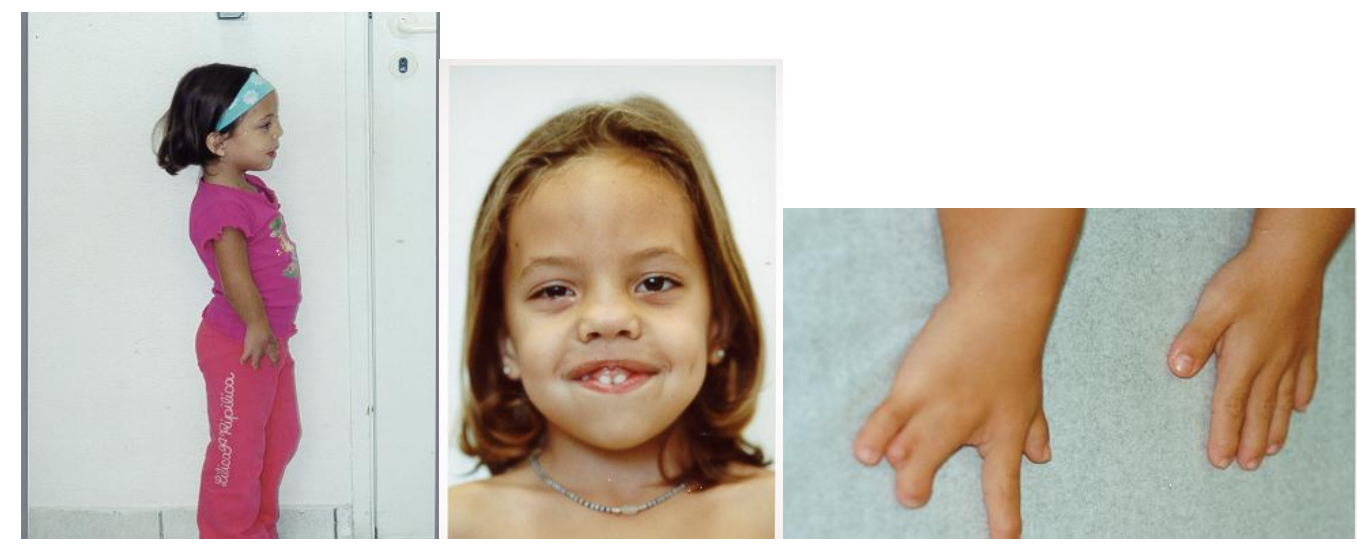

Figura 23: Imagens a/b/c da paciente 8 aos 10 anos de idade 


\section{Heredograma}

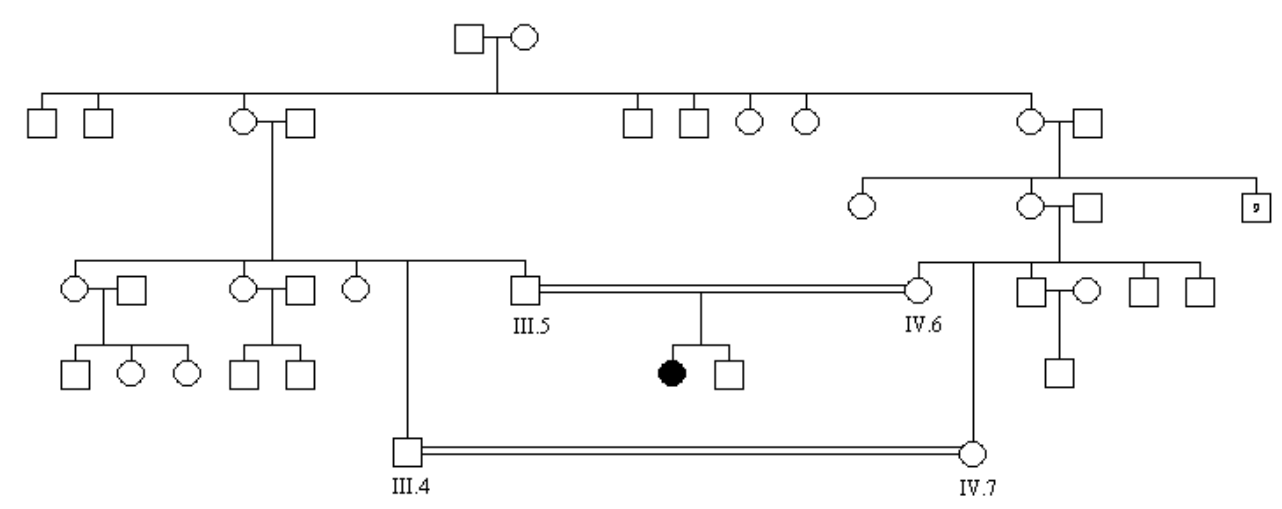

Figura 24: Heredograma da paciente 8

\section{Paciente 9}

Paciente do sexo masculino, brasileiro, filho de pais consangüíneos, sem outros casos na família. Foi encaminhado pelo Departamento de Genética da UNIFESP e examinado pela primeira vez aos cinco anos e seis meses. Nasceu de parto cesáreo, pesando $2500 \mathrm{~g}$ $\left(3^{\circ}\right.$ percentil $)$ e medindo $40 \mathrm{~cm}\left(<3^{\circ}\right.$ percentil $)$. Ao exame clínico notou-se: baixa estatura $\left(88 \mathrm{~cm},<3^{\circ}\right.$ percentil), bossa frontal, calvície frontal, hipoplasia de face média, cílios longos, hipertelorismo, ponte nasal larga, narinas antevertidas, nariz com fenda mediana pronunciada, filtro longo, fenda labial e palatina, boca triangular, cantos da boca voltados para baixo, língua bífida, micrognatia, má-oclusão dentária. Tinha pectus excavatum, hérnia inguinal. Sua genitália era hipoplásica, com micropênis, criptorquidia e hipoplasia de saco escrotal. Possui encurtamento predominantemente mesomélico. As mãos tinham braquidactilia, polegares alargados, displasia de unhas e clinodactilia; os 
pés apresentavam hálux alargado, aumento da distância entre o $1^{\circ}$ e $2^{\circ}$ artelhos. Exames ultrassonográficos revelaram rins de dimensões diminuídas.

A

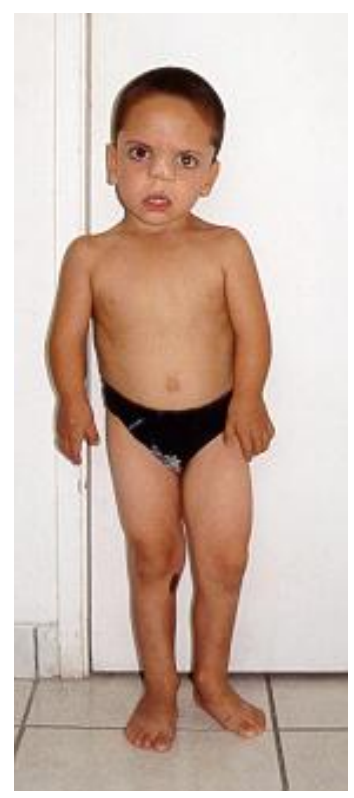

b

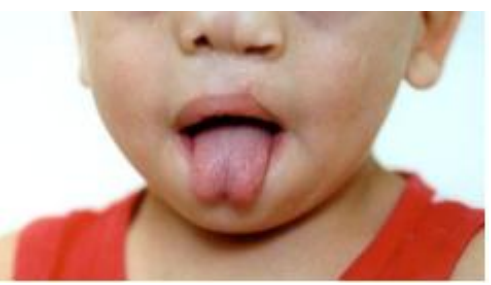

c

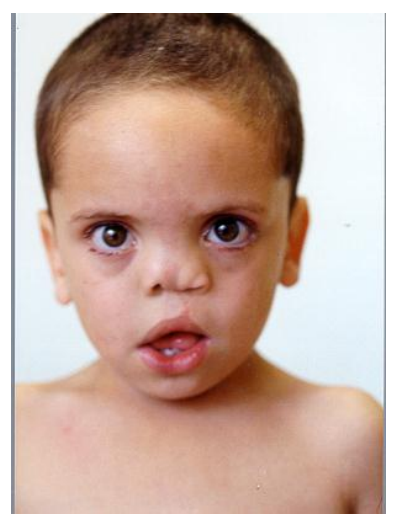

Figura 25: Imagens a/b/c do paciente 9 aos cinco anos e seis meses de idade

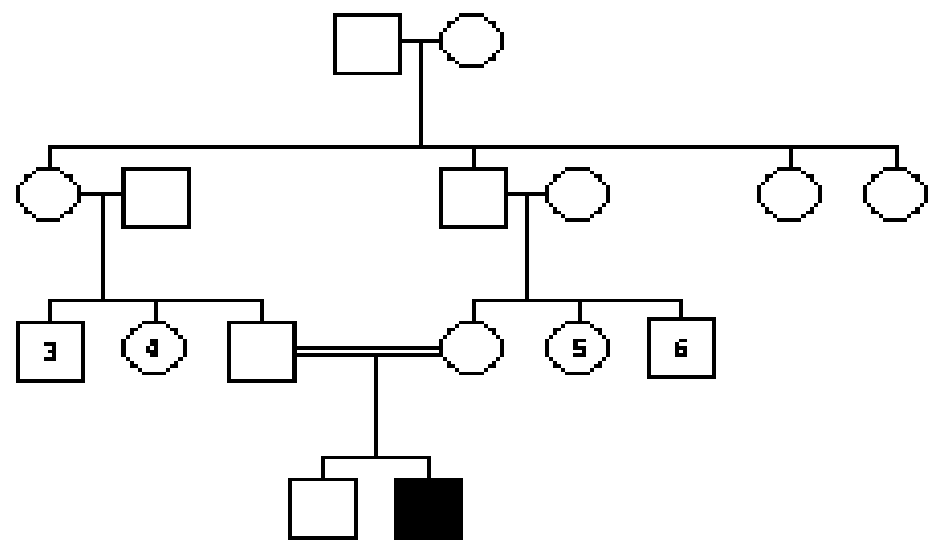

Figura 26: Heredograma do paciente 9 


\section{Paciente 10}

Paciente do sexo masculino nascido em 1993, filho de um casal consanguíneo, com duas irmãs não afetadas de origem Turca. Ao exame clínico observou-se testa proeminente, hipertelorismo, nariz curto com narinas antevertidas, ponte nasal larga e baixa, hipoplasia do terço médio da face, língua bífida, retrognatia, fusão de costelas, hemivertebras, braquidactilia, clinodactilia, polegares alargados, micropênis, criptorquidia, baixa estatura e encurtamento de membros.

a

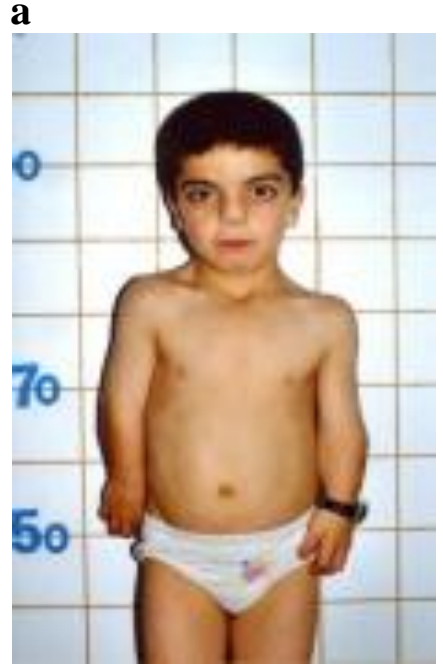

b

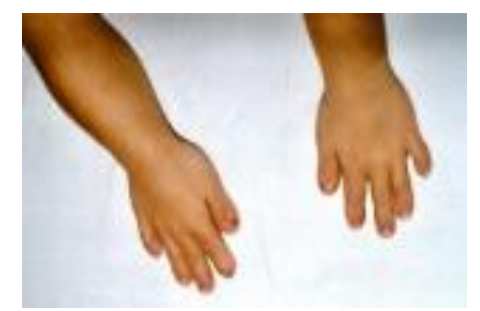

Figura 27: Imagens a/b paciente 10 


\section{Heredograma}

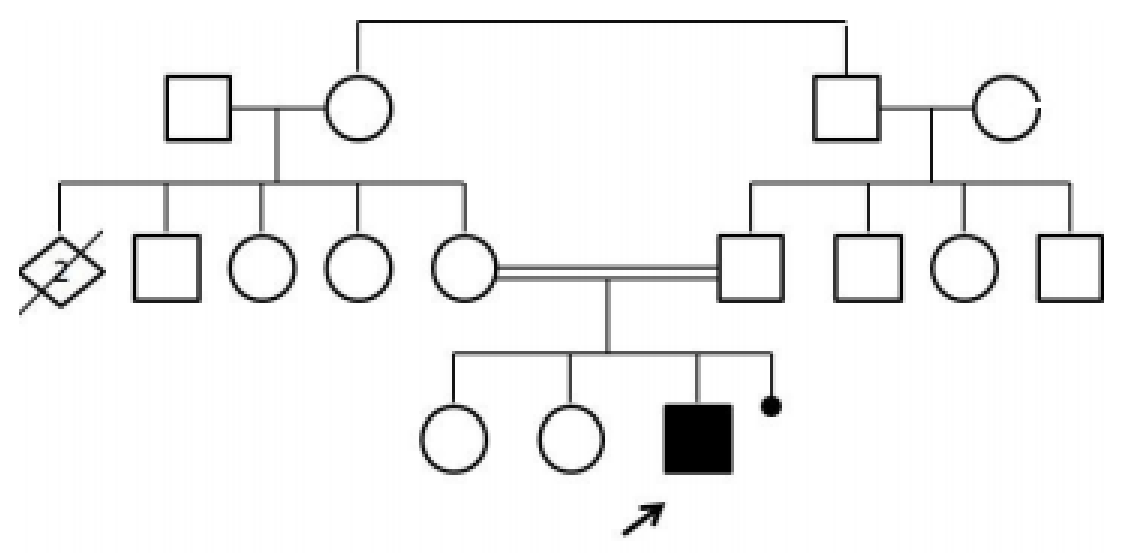

Figura 28: Herodograma do paciente 10

\section{Paciente 11}

Paciente do sexo masculino, brasileiro nascido em 1966, filho de casal consanguíneo.

Ao exame clinico observou-se baixa estatura, bossa frontal, pescoço curto, narinas antevertidas, micro pênis, criptoquidismo, escoliose, fusão de várias vertebras, encurtamentos de membros superiores.

$\mathbf{a}$

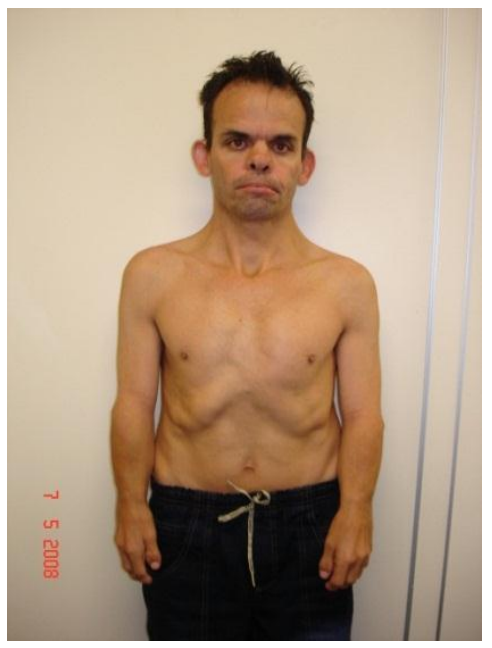

b

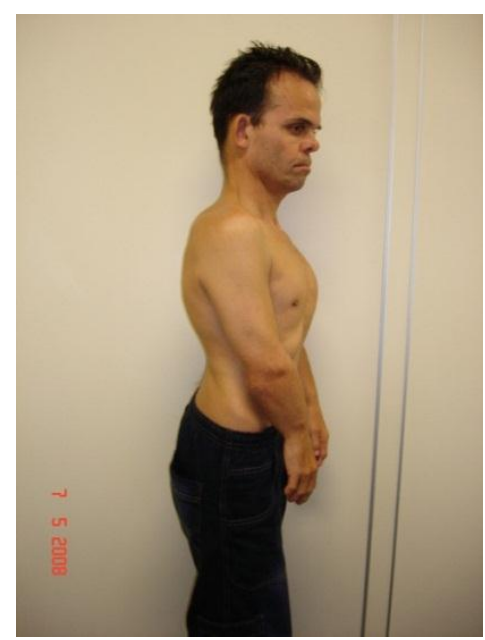

Figura 28: Imagens a/b do paciente 11 


\section{IV.2 Diagnóstico Molecular}

O principal objetivo do trabalho foi detectar novas mutações no gene $R O R 2 \mathrm{em}$ pacientes com síndrome de Robinow, forma autossômica recessiva. Sete dos 11 pacientes apresentaram mutações em homozigose e quatro eram heterozigotos compostos. As mutações em homozigose foram encontradas nos pacientes em que foi reportada a existência de consanguinidade. A Figura 7 mostra algumas das mutações identificadas por sequenciamento Sanger nos pacientes 7, 8 e 9. Na Tabela 2 estão descritas as mutações identificadas, seu efeito na sequencia da proteína e o país de origem dos pacientes.

A

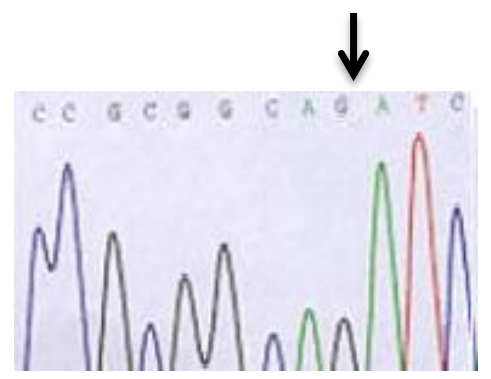

c.323G>A (exon 3)
C

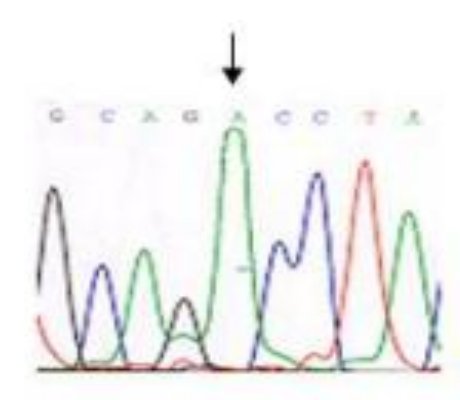

c.2273 C>A (exon 9)
B

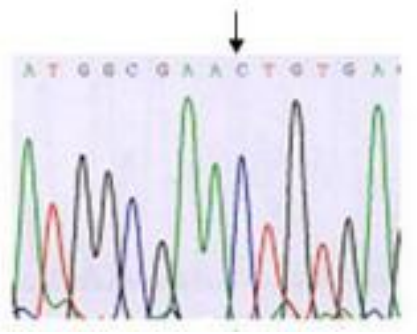

c.877delG (exon 6)

Figura 7: Exemplos de eletroferogramas com mutações identificadas por sequenciamento Sanger. 
Tabela 2 Mutações detectadas nos pacientes com SR autossômica recessiva, seu efeito na proteína e país de origem dos indivíduos.

\begin{tabular}{|c|c|c|c|c|c|c|}
\hline Paciente & $\begin{array}{c}\text { Exon } \\
\text { Alterado } \\
\end{array}$ & $\begin{array}{l}\text { Tipo de } \\
\text { Mutação } \\
\end{array}$ & $\begin{array}{l}\text { Alteração } \\
\text { de bases }\end{array}$ & Proteina & $\begin{array}{l}\text { Domínio } \\
\text { alterado }\end{array}$ & $\begin{array}{l}\text { Origem } \\
\text { Étnica }\end{array}$ \\
\hline 11 & 3 & Troca de sentido & c. $323 \mathrm{G}>\mathrm{A}$ & R108Q & Ig-like & Brasil \\
\hline 7 & 3 & Troca de sentido & c. $323 \mathrm{G}>\mathrm{A}$ & R108Q & Ig-like & Brasil \\
\hline 5 & 3 & Troca de sentido & c. $355 \mathrm{C}>\mathrm{T}^{* *}$ & R119X & Ig- like & \multirow{2}{*}{ Turquia } \\
\hline \multirow{3}{*}{3} & 5 & Perda de sentido & c. $613 \mathrm{C}>\mathrm{T} * *$ & R205X & Rico em cisteina & \\
\hline & 3 & Perda de sentido & c. $248 \mathrm{G}>\mathrm{A}$ & C83Y & Ig- Like & \multirow{2}{*}{ Brasil } \\
\hline & 9 & Troca de sentido & c. $1642 \mathrm{C}>\mathrm{T}$ & P548S & Rico em cisteina & \\
\hline 10 & 4 e 5 & $\begin{array}{l}\text { Mudança no quadro } \\
\text { de leitura }\end{array}$ & Del+ & & Ig-like & Turquia \\
\hline \multirow[t]{2}{*}{2} & 5 & Perda de sentido & c. $613 \mathrm{C}>\mathrm{T} * *$ & R205X & Ig-like & \multirow{2}{*}{ EUA } \\
\hline & 8 & Perda de sentido & c. $1189 \mathrm{C}>\mathrm{T} * *$ & R397X & Rico em cisteina & \\
\hline \multirow[t]{2}{*}{4} & 6 & Troca de sentido & c. $899 \mathrm{G}>\mathrm{T}$ & $\mathrm{C} 300 \mathrm{~F}$ & Rico em cisteina & \multirow[b]{2}{*}{ EUA } \\
\hline & 7 & Perda de sentido & Del c+ & & & \\
\hline 6 & 6 & Troca de sentido & c. $717 \mathrm{C}>\mathrm{A}$ & C239X & Rico em cisteina & Brasil \\
\hline 8 & 6 & $\begin{array}{l}\text { Mudança no quadro } \\
\text { de leitura }\end{array}$ & & $\mathrm{E} 293 f_{s} \mathrm{X} 444$ & Rico em cisteina & Brasil \\
\hline 9 & 9 & Troca de sentido & c. $2273 \mathrm{C}>\mathrm{A}$ & P692T & Tirosina-quinase & Brasil \\
\hline 1 & 9 & Troca de sentido & c. $1516 \mathrm{~A}>\mathrm{T}$ & $\mathrm{I} 506 \mathrm{~F}$ & Rico em cisteina & India \\
\hline
\end{tabular}

**Mutações já descritas na literatura

+ Mutação identificada em outro laboratório 
O Paciente 10 apresenta uma deleção de dois exons inteiros, exons 4 e 5 . O paciente foi investigado por MLPA por não ter sido possível amplificar os exons 4 e 5 por sequenciamento Sanger após repetidas tentativas Figura 8.

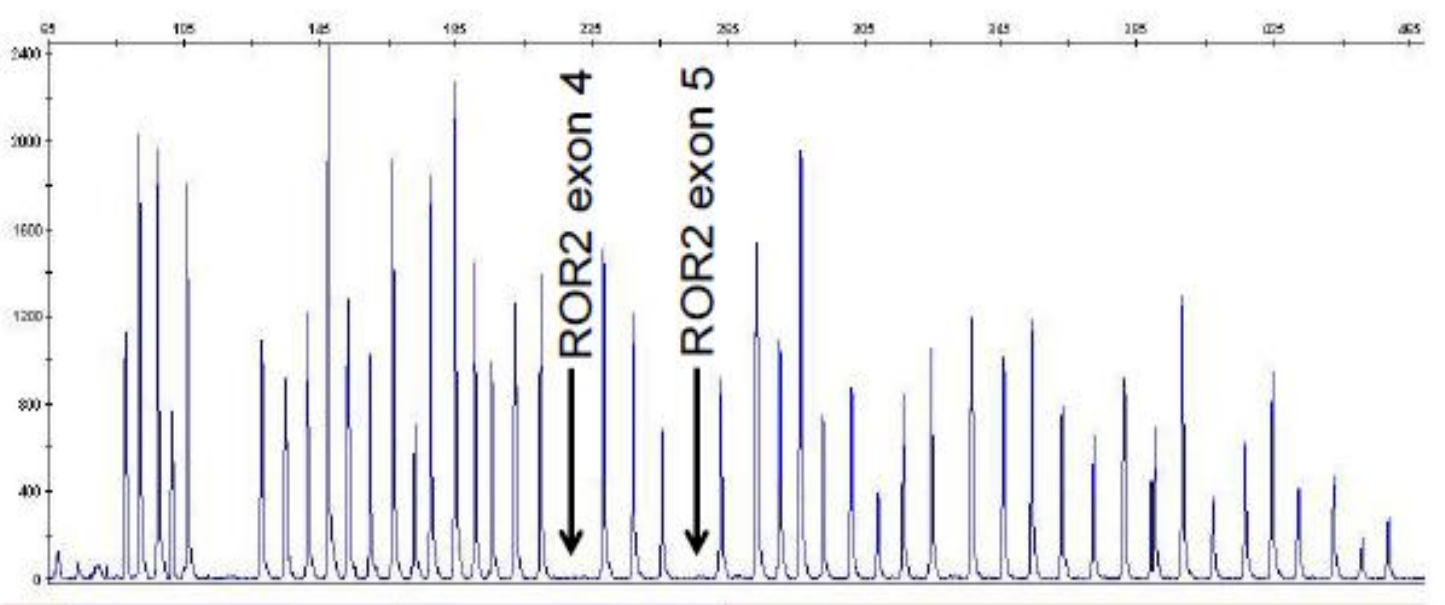

Figura 8: Análise de número de cópias do gene ROR2 por MLPA. As setas indicam a deleção em homozigose dos exons 4 e 5 do gene.

$\mathrm{Na}$ literatura foram reportadas até o momento 19 diferentes mutações como mostra a Tabela 3. Comparando os nossos resultados com os previamente descritos observamos que das treze mutações diferentes identificadas em nosso trabalho, apenas quatro já haviam sido reportadas na literatura.

Tabela 3: Mutações reportadas na literatura em pacientes com a forma autossômica recessiva da síndrome de Robinow. Dados obtidos de Van Bokhoven e cols. (2000), Afzal e cols. (2000b), Tufan e cols. 2005, Parag e cols 2014, Cybel e cols 2012. 


\begin{tabular}{|c|c|c|c|c|c|}
\hline Tipo de mutação & $\begin{array}{c}\text { Alteração de } \\
\text { bases }\end{array}$ & $\begin{array}{c}\text { Exon } \\
\text { alterado }\end{array}$ & $\begin{array}{l}\text { Alteração de } \\
\text { aminoácidos }\end{array}$ & $\begin{array}{c}\text { Número de } \\
\text { pacientes }\end{array}$ & Origem étnica \\
\hline Troca de sentido & c. $227 \mathrm{G}>\mathrm{A}$ & 3 & G76D & 1 & Índia \\
\hline Troca de sentido & c. $355 \mathrm{C}>\mathrm{T}$ & 3 & R119X & 1 & Turquia \\
\hline Perda de sentido & c. $545 \mathrm{G}>\mathrm{A}$ & 5 & $\mathrm{C} 182 \mathrm{Y}$ & 2 & Turquia/Índia \\
\hline Troca de sentido & c. $550 \mathrm{C}>\mathrm{T}$ & 5 & $\mathrm{R} 184 \mathrm{C}$ & 3 & $\begin{array}{l}\text { Brasil/ } \\
\text { Alemanha }\end{array}$ \\
\hline Troca de sentido & c. $565 \mathrm{C}>\mathrm{T}$ & 5 & R189W & 1 & Paquistão \\
\hline Troca de sentido & c. $574 \mathrm{~T}>\mathrm{G}$ & & Y192D & 1 & Egito \\
\hline Perda de sentido & c. $613 \mathrm{C}>\mathrm{T}$ & 5 & $\mathrm{R} 205 \mathrm{X}$ & 3 & Turquia \\
\hline Whole-exon deletion & & $6-7$ & & 1 & Texas \\
\hline Troca de sentido & c. $668 \mathrm{G}>\mathrm{A}$ & 6 & $\mathrm{C} 223 \mathrm{Y}$ & 1 & Íindia \\
\hline Troca de sentido & c. $730 \mathrm{C}>\mathrm{T}$ & 6 & R244W & 1 & UK \\
\hline Troca de sentido & c. $733 \mathrm{G}>\mathrm{A}$ & 6 & $\mathrm{~A} 245 \mathrm{~T}$ & 1 & UK \\
\hline Troca de sentido & c. $814 \mathrm{C}>\mathrm{T}$ & 6 & $\mathrm{R} 272 \mathrm{C}$ & 1 & Líbano \\
\hline Troca de sentido & c. $1096 \mathrm{C}>\mathrm{T}$ & 7 & R366W & 1 & Paquistão \\
\hline Perda de sentido & c. $1189 \mathrm{C}>\mathrm{T}$ & 8 & R397X & 1 & Turquia \\
\hline Perda de sentido & c. $1504 \mathrm{C}>\mathrm{T}$ & 9 & Q502X & 14 & Oman \\
\hline $\begin{array}{l}\text { Mudança no quadro } \\
\text { de leitura }\end{array}$ & c. $1740-1774 \mathrm{del}$ & 9 & D580fsX124 & 1 & Paquistão \\
\hline Troca de sentido & c. $1860 \mathrm{~T}>\mathrm{A}$ & 9 & N620K & 1 & Turquia \\
\hline $\begin{array}{l}\text { Mudança no quadro } \\
\text { de leitura }\end{array}$ & c.1937-1943del & 9 & Y646fsX56 & 1 & Turquia \\
\hline Perda de sentido & c. $2160 \mathrm{G}>\mathrm{A}$ & 9 & W720X & 1 & Turquia \\
\hline
\end{tabular}

As mutações recorrentes foram previamente descritas em pacientes da Turquia. $\mathrm{O}$ Paciente 5, apresenta duas mutações já descritas e também é da Turquia. No entanto, a Paciente 2 é heterozigota composta para duas mutações descritas em pacientes da Turquia, mas é americana. Não temos informações sobre a ancestralidade da paciente, no entanto não há relato de origem turca em parentes próximos.

As primeiras descrições, e o maior número de relatos da forma autossômica recessiva da síndrome de Robinow foram de famílias turcas devido ao alto índice de casamentos consanguíneos que ocorrem na região. Na Figura 6 pode-se observar a estrutura do receptor ROR2 seus domínios extracelular e intracelular com apresentação das mutações já descritas pela literatura no lado A da figura e descrição das mutações detectadas nos pacientes participantes da pesquisa no lado $\mathbf{B}$. 
A

B

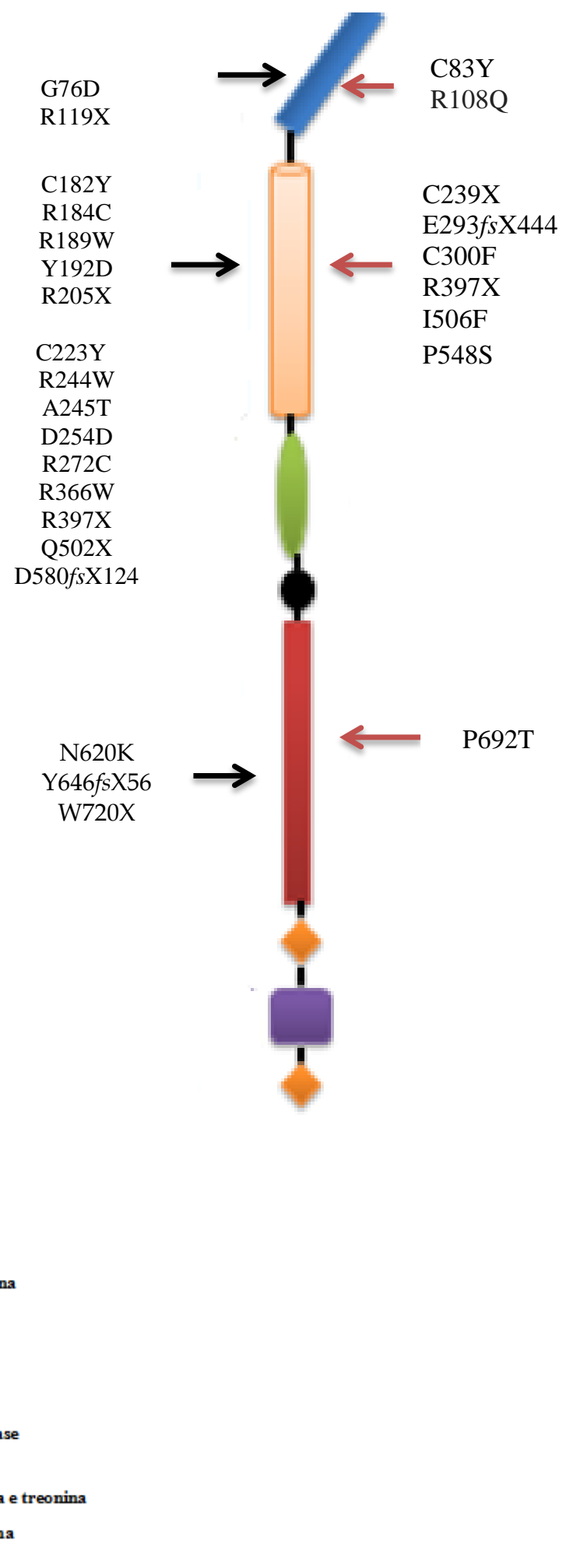

Figura 9: Estrutura do receptor ROR2 com alteracoes dos aminoacidos a. já descritas na literatura no lado esquerdo da figura. b. mutações não descritas detectadas nos pacientes participantes da pesquisa. 
Huang e cols., 2014 relatam que alterações no gene ROR2 também estão envolvidas com a braquidactilia tipo B que apresenta como principal característica a deficiência nas estruturas terminais dos dedos das mãos e pés. As mutações já detectadas alteram aminoácidos em regiões interdomínios, próximas ao domínio tirosina-quinase e tem como resultado a produção de uma proteína alterada devido a um ganho de função.

A família de receptores tirosina-quinase corresponde a um grupo de receptores que realizam interações proteína-proteína em várias vias. Cada domínio tem uma função diferente; por exemplo, alterações no domínio rico em cisteina podem afetar ligações dissulfeto e dobramento da proteína, ou alterações no domínio tirosina quinase alterariam o processo de fosforilação. No entanto, Ali e Cols.,2007, observaram que mutações por substituição de aminoácidos no domínio rico em cisteína levam à retenção da proteína mutada no retículo endoplasmático, o que pode ocorrer também com mutações que afetam outros domínios.

Em uma família do Libano foram descritas duas meninas, filhas de um casal consanguíneo, com manifestações ósseas muito leves, portadoras de mutação em homozigose no exon 6 (c.814C>T), que altera um aminoácido no domínio rico em cisteína, R272C. Apesar dessa mesma mutação não ter sido descrita em outros pacientes, mutações afetando esse domínio foram descritas em pacientes com fenótipos mais graves. Esses autores propuseram que uma possível retenção parcial da proteína no retículo endoplasmático poderia explicar a menor gravidade do quadro clinico (Cybel e cols.,2012).

$\mathrm{Na}$ nossa amostra, o paciente quatro apresenta manifestações ósseas mais graves. A paciente 8 apresenta ectrodactilia. Esses dois pacientes tem mutações que alteram o quadro de leitura e que poderiam causar efeito mais grave na proteína. Esses dados 
poderiam estar indicando a presença de uma possível correlação entre genótipo e fenótipo nos pacientes com mutação em ROR2. No entanto, o paciente 10 também apresenta uma grande deleção mas não há maior gravidade das malformações esqueléticas.

Por outro lado, observam-se poucas diferenças fenotípicas entre os pacientes com a forma recessiva. Na nossa amostra, também não observamos diferenças significativas nos quadros clínicos além das citadas acima. Outros estudos funcionais ainda precisam ser realizados para elucidar se de fato há perda total de função de ROR2 independente do tipo de mutação como proposto por Ali e Cols,(2007).

O trabalho de Mazzeu e cols., em 2007 reportou a frequência de 75 sinais e sintomas em pacientes com as formas dominante e recessiva em pacientes novos e já descritos na literatura. Esse trabalho estimou as frequências de cada sinal levando em conta a possibilidade dele estar ou não ausente quando não era reportado. Além disso, a classificação dos pacientes na forma recessiva foi feita com base apenas na gravidade das manifestações esqueléticas, principalmente fusão de costelas, e não na presença de mutações no gene. Com base na descrição clínica de nossos pacientes (anexo 1) construímos a Tabela 4 que mostra as frequências encontradas no trabalho de Mazzeu e cols., (2007) e a presença desses sinais em nossa amostra. Importante ressaltar que foram adicionadas apenas as características com frequência $>25 \%$ de acordo com o trabalho de realizado por Mazzeu e cols., (2007). 


\begin{tabular}{|c|c|c|c|c|c|c|c|c|c|c|c|c|c|c|}
\hline Característica & $\%$ & $\mathbf{n}$ & $\%$ & PCT 1 & PCT 2 & PCT 3 & PCT 4 & PCT 5 & PCT 6 & PCT 7 & PCT 8 & PCT 9 & PCT 10 & PCT 11 \\
\hline Hipertelorismo & 100 & $11 / 11$ & 100 & $\mathrm{X}$ & $\mathrm{X}$ & $\mathrm{X}$ & $\mathrm{X}$ & $\mathrm{X}$ & $\mathrm{X}$ & $\mathrm{X}$ & $\mathrm{X}$ & $\mathrm{X}$ & $\mathrm{X}$ & $\mathrm{X}$ \\
\hline Encurtamento dos Membros & 100 & $11 / 11$ & 100 & $\mathrm{X}$ & $\mathrm{X}$ & $\mathrm{X}$ & $X$ & $\mathrm{X}$ & $X$ & $\mathrm{X}$ & $\mathrm{X}$ & $\mathrm{X}$ & $X$ & $\mathrm{X}$ \\
\hline Micropênis & 100 & 06/06 & 100 & $\mathrm{Y}$ & $\mathrm{Y}$ & $\mathrm{Y}$ & $X$ & $\mathrm{Y}$ & $\mathrm{X}$ & $\mathrm{X}$ & $\mathrm{Y}$ & $\mathrm{X}$ & $X$ & $\mathrm{X}$ \\
\hline Fusão de costelas & 100 & $10 / 11$ & 91 & $X$ & $\mathrm{X}$ & $\mathrm{X}$ & $X$ & $\mathrm{X}$ & A & $\mathrm{X}$ & $\mathrm{X}$ & $\mathrm{X}$ & $\mathrm{X}$ & $\mathrm{X}$ \\
\hline Hemivértebra & 97,5 & $08 / 11$ & 72 & $X$ & $\mathrm{X}$ & $\mathrm{X}$ & $X$ & $X$ & $\mathrm{X}$ & $\mathrm{X}$ & NR & NR & $X$ & NR \\
\hline Baixa Estatura & 97,3 & $11 / 11$ & 100 & $X$ & $\mathrm{X}$ & $\mathrm{X}$ & $X$ & $\mathrm{X}$ & $X$ & $\mathrm{X}$ & $\mathrm{X}$ & $\mathrm{X}$ & $X$ & $\mathrm{X}$ \\
\hline Nariz curto & 97 & $11 / 11$ & 100 & $X$ & $\mathrm{X}$ & $\mathrm{X}$ & $X$ & $\mathrm{X}$ & $\mathrm{X}$ & $\mathrm{X}$ & $X$ & $\mathrm{X}$ & $X$ & $X$ \\
\hline Narinas Antevertidas & 96,2 & $11 / 11$ & 100 & $X$ & $\mathrm{X}$ & $\mathrm{X}$ & $X$ & $X$ & $\mathrm{X}$ & $\mathrm{X}$ & $X$ & $\mathrm{X}$ & $X$ & $\mathrm{X}$ \\
\hline Cantos da Boca Voltado para Baixo & 95,2 & $09 / 11$ & 81 & $\mathrm{X}$ & $\mathrm{X}$ & $\mathrm{X}$ & $\mathrm{X}$ & $\mathrm{X}$ & $\mathrm{X}$ & A & $\mathrm{X}$ & $\mathrm{X}$ & A & $\mathrm{X}$ \\
\hline Ponte Nasal Larga & 94,8 & $10 / 11$ & 91 & $\mathrm{X}$ & $\mathrm{X}$ & $\mathrm{X}$ & $\mathrm{X}$ & $\mathrm{X}$ & $\mathrm{X}$ & $\mathrm{X}$ & $\mathrm{X}$ & $\mathrm{X}$ & $X$ & A \\
\hline Hipoplasia Terço Médio da Face & 94,2 & $10 / 11$ & 91 & $\mathrm{X}$ & $\mathrm{X}$ & $\mathrm{X}$ & $\mathrm{X}$ & $\mathrm{X}$ & $\mathrm{X}$ & NR & $X$ & $\mathrm{X}$ & $\mathrm{X}$ & $\mathrm{X}$ \\
\hline Má Oclusão Dentária & 93,6 & $03 / 11$ & 27 & NR & A & NR & $\mathrm{X}$ & NR & $\mathrm{X}$ & NR & $\mathrm{X}$ & NR & A & NR \\
\hline Nariz curto & 93,2 & $11 / 11$ & 100 & $\mathrm{X}$ & $\mathrm{X}$ & $X$ & $\mathrm{X}$ & $X$ & $\mathrm{X}$ & $X$ & $X$ & $\mathrm{X}$ & $X$ & $\mathrm{X}$ \\
\hline Braquidactilia & 91,4 & $11 / 11$ & 100 & $\mathrm{X}$ & $\mathrm{X}$ & $\mathrm{X}$ & $\mathrm{X}$ & $\mathrm{X}$ & $\mathrm{X}$ & $\mathrm{X}$ & $\mathrm{X}$ & $\mathrm{X}$ & $\mathrm{X}$ & $\mathrm{X}$ \\
\hline Clinodactilia & 87,8 & $07 / 11$ & 63 & NR & $\mathrm{X}$ & $\mathrm{X}$ & $X$ & A & $\mathrm{X}$ & NR & $X$ & $\mathrm{X}$ & $X$ & NR \\
\hline Boca triangular & 86,2 & $08 / 11$ & 72 & $\mathrm{X}$ & $\mathrm{X}$ & $\mathrm{X}$ & $\mathrm{X}$ & A & $\mathrm{X}$ & $\mathrm{A}$ & $\mathrm{X}$ & $\mathrm{X}$ & $\mathrm{A}$ & $\mathrm{X}$ \\
\hline Pequenos Lábios Hipoplásicos & 80,8 & $04 / 05$ & 80 & A & $\mathrm{X}$ & $\mathrm{X}$ & $\mathrm{Y}$ & $\mathrm{X}$ & $\mathrm{Y}$ & $\mathrm{Y}$ & $X$ & $\mathrm{Y}$ & $\mathrm{Y}$ & $\mathrm{Y}$ \\
\hline Clitóris Hipoplásico & 79,4 & $03 / 05$ & 60 & $\mathrm{~A}$ & $\mathrm{X}$ & $\mathrm{X}$ & $\mathrm{Y}$ & $\mathrm{A}$ & $\mathrm{Y}$ & $\mathrm{Y}$ & $\mathrm{X}$ & $\mathrm{Y}$ & $\mathrm{Y}$ & $\mathrm{Y}$ \\
\hline Testa Proeminente & 77,8 & $10 / 11$ & 91 & $X$ & $\mathrm{X}$ & $\mathrm{X}$ & $X$ & NR & $X$ & $\mathrm{X}$ & $\mathrm{X}$ & $\mathrm{X}$ & $X$ & $X$ \\
\hline Escoliose & 77,4 & $07 / 11$ & 63 & $\mathrm{~A}$ & $\mathrm{X}$ & $\mathrm{X}$ & $X$ & $\mathrm{~A}$ & A & $\mathrm{X}$ & $\mathrm{X}$ & $\mathrm{X}$ & $\mathrm{A}$ & $\mathrm{X}$ \\
\hline Hiperplasia gingival & 71,4 & $06 / 11$ & 54 & $\mathrm{X}$ & $\mathrm{X}$ & $\mathrm{X}$ & $\mathrm{X}$ & $\mathrm{X}$ & A & NR & $\mathrm{X}$ & NR & A & NR \\
\hline Micrognatia & 68,2 & $07 / 11$ & 63 & $X$ & A & $\mathrm{X}$ & $X$ & $\mathrm{X}$ & $X$ & $\mathrm{X}$ & A & $\mathrm{X}$ & $\mathrm{A}$ & NR \\
\hline Criptorquidia & 66,7 & $04 / 06$ & 66 & $\mathrm{Y}$ & $\mathrm{Y}$ & $\mathrm{Y}$ & A & $\mathrm{Y}$ & A & $\mathrm{X}$ & $\mathrm{Y}$ & $\mathrm{X}$ & $\mathrm{X}$ & $X$ \\
\hline Cílios Longos & 58,8 & $08 / 11$ & 72 & $\mathrm{X}$ & $\mathrm{X}$ & $\mathrm{X}$ & $X$ & NR & $X$ & $\mathrm{X}$ & $\mathrm{X}$ & $X$ & $\mathrm{~A}$ & NR \\
\hline
\end{tabular}




\begin{tabular}{|c|c|c|c|c|c|c|c|c|c|c|c|c|c|c|}
\hline Característica & $\%$ & $\mathbf{n}$ & $\%$ & PCT 1 & PCT 2 & PCT 3 & PCT 4 & PCT 5 & PCT 6 & PCT 7 & PCT 8 & PCT 9 & PCT 10 & PCT 11 \\
\hline Lingua Bífida & 58,5 & $11 / 11$ & 100 & $\mathrm{X}$ & $\mathrm{X}$ & $\mathrm{X}$ & $\mathrm{X}$ & $\mathrm{X}$ & $\mathrm{X}$ & $\mathrm{X}$ & $\mathrm{X}$ & $\mathrm{X}$ & $\mathrm{X}$ & $\mathrm{X}$ \\
\hline Ponte Nasal Baixa & 48,7 & $07 / 11$ & 63 & $\mathrm{X}$ & A & $\mathrm{X}$ & $\mathrm{X}$ & $\mathrm{X}$ & A & $\mathrm{X}$ & $\mathrm{X}$ & $\mathrm{A}$ & $\mathrm{X}$ & A \\
\hline Hipoplasia Grandes Lábios & 39,8 & $01 / 05$ & 20 & A & $\mathrm{X}$ & $\mathrm{A}$ & $\mathrm{Y}$ & A & $\mathrm{Y}$ & $\mathrm{Y}$ & A & $\mathrm{Y}$ & $\mathrm{Y}$ & $\mathrm{Y}$ \\
\hline Retrognatia & 36,6 & $06 / 11$ & 54 & $X$ & A & $\mathrm{X}$ & $X$ & $\mathrm{X}$ & A & NR & $\mathrm{X}$ & $\mathrm{A}$ & $X$ & NR \\
\hline Polegares alargados & 30,6 & $06 / 11$ & 54 & NR & $\mathrm{X}$ & $\mathrm{X}$ & $\mathrm{A}$ & $\mathrm{X}$ & NR & $\mathrm{X}$ & A & $\mathrm{X}$ & $\mathrm{X}$ & A \\
\hline Pectus Excavatum & 30,6 & $06 / 11$ & 54 & NR & $\mathrm{X}$ & $\mathrm{X}$ & NR & NR & $\mathrm{X}$ & NR & $\mathrm{X}$ & $\mathrm{X}$ & $\mathrm{A}$ & $\mathrm{X}$ \\
\hline Lábio Superior Fino & 29 & $08 / 11$ & 72 & $\mathrm{X}$ & $\mathrm{X}$ & $\mathrm{X}$ & $\mathrm{X}$ & A & A & $\mathrm{X}$ & $\mathrm{X}$ & $\mathrm{X}$ & $\mathrm{A}$ & $X$ \\
\hline Origem Geográfica & & & & Índia & EUA & Brasil & EUA & Turquia & Brasil & Brasil & Brasil & Brasil & Turquia & Brasil \\
\hline Sexo & & & & Fem & Fem & Fem & Mas & Fem & Mas & Mas & Fem & Mas & Mas & Mas \\
\hline
\end{tabular}


Observamos que os nossos pacientes apresentam frequências semelhante as do trabalho de Mazzeu e cols., (2007) para a maior parte dos sinais clínicos. A primeira exceção foi a fusão de costelas que estava ausente no paciente 6 e que foi considerada como critério para a classificação na forma recessiva no trabalho anterior.

A má oclusão dentária foi uma característica em que houve uma de frequência destoante entre os dois trabalhos, pois a literatura apresenta 93,6\% e no nosso trabalho apenas três dos 11 pacientes tinham má oclusão. No entanto esse foi o sinal clínico com maior número de casos em que o sinal não foi assinalado nem como presente nem como ausente, o que poderia explicar essa discrepância.

A língua bífida estava presente em $100 \%$ dos pacientes do nosso trabalho enquanto que no trabalho anterior a frequência era de 58,5\%. Esse sinal se mostrou fundamental para a caracterização da síndrome, sendo também frequente na forma autossômica dominante (38,5\% segundo o trabalho de Mazzeu e cols., 2007).

Outro sinal discrepante foi o lábio superior fino que apresentou uma frequência de $72 \%$ no presente trabalho e $29 \%$ no trabalho anterior. Os dados acima corroboram a hipótese de que sinais clínicos mais leves como língua bífida e lábio superior fino são mais frequentemente não reportados nos artigos do que os sinais mais graves. Vale ressaltar que cinco dos nossos pacientes foram também incluídos no trabalho de Mazzeu (2007).

As demais características se apresentam em conformidade de frequência quando comparamos os dois trabalhos, ressaltando as principais características clínicas apresentadas pelos portadores da síndrome. A alta frequência encontrada para a maioria dos sinais consolida ainda mais a ideia da relação genótipo/fenótipo, pois o grupo de pacientes, mesmo com mutações diferentes, se apresentou homogêneo com relação aos sinais clínicos. 
Após a identificação dos principais genes envolvidos na forma autossômica dominante será possível realizar uma melhor caracterização clínica das diferentes formas da síndrome e os dados do presente trabalho certamente contribuirão para a melhor caracterização da forma recessiva. 


\section{Conclusões}

Em nossa pesquisa, trabalhamos com 11 pacientes afetados pela forma autossômica recessiva da Síndrome de Robinow e em todos identificamos mutações no gene ROR2. Das 13 mutações diferentes detectadas 10 nunca foram descritas na literatura e, portanto, nosso trabalho contribui para composição do quadro de mutações já descritas, cooperando para composição das mutações mais frequentes auxiliando assim o diagnóstico molecular e aconselhamento genético.

A descrição clínica detalhada dos pacientes com diagnóstico confirmado molecularmente contribuiu para a definição das frequências dos principais sinais clínicos nessa forma da síndrome. 


\section{Referências Bibliográficas}

AFZAL AR, RAJAB A, FENSKE C, CROSBY A, LAHIRI N, TERNES-PEREIRA E,MURDAY VA, HOULSTON R, PATTON MA, JEFFERY S. Linkage of recessive Robinow syndrome to a $4 \mathrm{cM}$ interval on chromosome 9q22. Hum Genet 2000;106:351-4.

AKŞIT S, AYDINLIOGLU H, DIZDARER G, CAGLAYAN S, BEKTAŞLAR D, CIN A. Is the frequency of Robinow syndrome relatively high in Turkey? Four more case reports. Clin Genet. 1997 52(4):226-30.

ALI BR, JEFFERY S, PATEL N, TINWORTH LE, MEGUID N, PATTON MA, AFZAL AR. Novel Robinow syndrome causing mutations in the proximal region of the frizzled-like domain of ROR2 are retained in the endoplasmic reticulum. Hum Genet. 2007; 122.

BEN-SHACHAR S, KHAJAVI M, WITHERS MA, SHAW CA, VAN BH, BRUNNER HG, LUPSKI JR. Dominant versus recessive traits conveyed by allelic mutations to what extent is nonsense-mediated decay involved?. Clin Genet 2009: 75: 394-400.

BILLIARD J, DEANA S. WAY, LAURA M. SEESTALLER-WEHR, ROBERT A. MORAN, ANNAMARIE MANGINE, AND PETER V. N. BODINE. The Orphan Receptor Tyrosine Kinase Ror2 Modulates Canonical Wnt Signaling in Osteoblastic Cells Molecular Endocrinology 2006 19(1):90-101.

CYBEL M, ELIANE C, DIANE M, GENEVIÈVE B, MARTINE L. M, VALÉRIE CORMIER D. Identification of a novel causative mutation in the ROR2 gene in a Lebanese family with a mild form of recessive Robinow syndrome. European Journal of Medical Genetics 2012, 103 e 108.

DONALD A. G, PETER BIALEK, JONG DEOK AHN, MICHAEL STARBUCK, MILLAN S. PATEL, HANS CLEVERS, MARK M. TAKETO, FANXIN LONG, ANDREW P. MCMAHON, RICHARD A. LANG. Canonical Wnt Signaling in Differentiated Osteoblasts Controls Osteoclast Differentiation. Developmental Cell, 2006 Vol. 8, 751-764.

FATIH T, KIVANC CEFLE, SEVAL TU RKMEN,AYDIN TU“ RKMEN UNAL ZORBA, MEMDUH DURSUN, SU KRU OZTU RK, SU KRU PALANDU Z, TEVFIK ECDER, STEFAN MUNDLOS, AND DENISE HORN. Clinical and Molecular Characterization of Two Adults With Autosomal Recessive Robinow Syndrome. American Journal of Medical Genetics. 2005 136A:185-189

HE F, XIONG W, YU X, ESPINOZA-LEWIS R,LIU C, GU S, NISHITA M, SUZUKI K,YAMADA G, MINAMI Y, CHEN Y. Wnt5a regulates directional cell migrationand cell proliferation via Ror2-mediated noncanonical pathway inmammalian palate development. Development 2008 135:3871-3879 
HUANG D, JIANG S, ZHANG Y, LIU X, ZHANG J, HE R . A new mutation in the gene ROR2 causes brachydactyly type B1. Gene. 2014 Aug 15;547(1):106-10.

KAZUHIRO M, NAOYUKI T, YASUHIRO KOBAYASHI J. Roles of Wnt signals in bone resorption during physiologicaland pathological states. Mol Med 2013. 91:15-23

KIERAN J. BUNN' PHIL DANIEL' HELEEN S. RÖSKEN, ADAM C. O'NEILL' SOPHIA R. CAMERON-CHRISTIE, TIM MORGAN, HAN G. BRUNNER' ANGELINE LAI, HENRICUS P.M. KUNST, DAVID M. MARKIE, STEPHEN P. ROBERTSON Mutations in DVLl Cause an Osteosclerotic Form of Robinow Syndrome. Cell 2015, Pages 623-630

MAZZEU JF, PARDONO E, VIANNA M. AM, RICHIERI C. A, AE KIM C, BRUNONI D, MARTELLI L. A. CE, COLIN G, OTTO PA. Clinical characterization of autosomal dominant and recessive variants of Robinow syndrome. Am J Med Genet A. 2007;143(4):320-5.

OISHI I, SUZUKI H, ONISHI N ET AL. The receptor tyrosine kinase Ror2 is involved in non-canonical Wnt5a/JNK signalling pathway. Genes Cells 2003: 8 (7): 645-654.

PARAG M, LAKSHMI VASUDEVAN, SHWETA KONDURKAR, YASHASWINI K, SUNIL KUMAR AGARWALLA, MOHANDAS NAIR, RAMKUMAR TV, NITIN CHAUBAL, VASUNDHARA SRIDHAR CHENNURI. Identification of Novel ROR2 Gene Mutations in Indian Children withRobino w Syndrome. J Clin Res Pediatr Endocrinol. 2014 ; 6(2): 79-83.

PATTON M, AFZAL AR. Robinow syndrome. Med Genet 2002; 39:305-310

PAUL T. SHARPE, YASUHIRO MINAMI,AND STEFAN MUNDLOS GEORG C. SCHWABE, BRITTA TREPCZIK, KATHRIN SU“RING, NORBERT BRIESKE, ABIGAIL S. TUCKER. Ror2 Knockout Mouse as a Model for the Developmental Pathology of Autosomal Recessive Robinow Syndrome. Developmental Dynamics. 2004 229:400-410.

PERSON AD, BEIRAGHI S, SIEBEN CM, HERMANSON S, NEUMANN AN, ROBU ME, SCHLEIFFARTH JR, BILLINGTON CJ JR, VAN BOKHOVEN H, HOOGEBOOM JM, MAZZEU JF, PETRYK A, SCHIMMENTI LA, BRUNNER HG, EKKER SC, LOHR JL. WNT5A mutations in patients with autosomal dominant Robinow syndrome. Dev dyn. 2010; 239(1):327-37.

POLAKIS, P. Wnt signaling in cancer. Cold Spring Harb. Perspect. Biol.2012 1;4(5).

ROBINOW M, SILVERMAN FN, SMITH HD. A newly recognized dwarfing syndrome. Am J Dis Child 1969;117:645-51. 
ROBINOW M. The Robinow (fetal face) syndrome: a continuing puzzle. Clin Dysmorphol 1993;2:189-98

ROEL N. Wnt signaling in disease and in development .Cell Research, 200515 (1) :2832 .

ROIFMAN M., MARCELIS C.L.M, PATON T., MARSHALL C., SILVER R., LOHR J.L., YNTEMA H.G., VENSELAAR H., KAYSERILI H., VAN BON B., SEAWARD G., FORGE CANADA CONSORTIUM, BRUNNER H.G., CHITAYAT D. De novo WNT5A-associated autosomal dominant Robinow syndrome suggests specificity of genotype and phenotype. Clin Genet 2014 : doi: 10.1111

SCHLESSINGER J Cell signaling by receptor tyrosine kinases Cell. 2000 13;103(2):211-25.

SCHWABE G, TREPCZIK B, KATHRIN S, BRIESKE N, TUCKER A,. SHARPE P, MINAMI Y, AND MUNDLOS S. Ror2 Knockout Mouse as a Model for the Developmental Pathology of Autosomal Recessive Robinow Syndrome. Developmental dynamics 2004; 229:400-410.

SHPRINTZEN RJ, GOLDBERG RB, SAENGER P, SIDOTI EJ. Male-to-male transmission of Robinow's syndrome. Its occurrence in association with cleft lip and cleft palate. Am J Dis Child. 1982 Jul;136(7):594-7.

VAN BOKHOVEN H, CELLI J, KAYSERILI H, BALCI S, BRUSSEL W,SKOVBY F, KERR B, PERCIN E, AKARSU N, BRUNNER HG. Mutation of the gene encoding the ROR2 tyrosine kinase causes autosomal recessive Robinow syndrome. Nat Genet 2000;25:423-6. Erratum in Nat Genet 2000;26:383

W. C. FORRESTER. Review The Ror receptor tyrosine kinase family Cell. Mol. Life Sci. 2002 83-96

WADIA R S. Recessively inherited costovertebral segmentation defect with mesomefia and peculiar facies (Covesdem syndrome) A new genetic entity? J Med Genet 1978, $15: 123 q 27$.

WHITE J, MAZZEU JF, HOISCHEN A, JHANGIANI SN, GAMBIN T, ALCINO MC, PENNEY S, SARAIVA JM, HOVE H, SKOVBY F, KAYSERILI H, ESTRELLA E, VULTO-VAN SILFHOUT AT, STEEHOUWER M, MUZNY DM, SUTTON VR, GIBBS RA; BAYLOR-HOPKINS CENTER FOR MENDELIAN GENOMICS, LUPSKI JR, BRUNNER HG, VAN BON BW, CARVALHO CM. DVL1 frameshift mutations clustering in the penultimate exon cause autosomal dominant Robinow syndrome. Am J Hum Genet. 2015 2;96(4):612-22.

WIBKE S, FLORIAN W, ANNA R, STEFAN M. AND SIGMAR STRICKER. A gradient of ROR2 protein stability and membrane localization confers brachydactyly type B or Robinow syndrome phenotypes. Human Molecular Genetics 2009, Vol. 18, No. 21 4013-4021. 
YAN L, BORIS RUBIN, PETER V.N. BODINE, AND JULIA BILLIARD Wnt5a Induces Homodimerization and Activation of Ror2 Receptor Tyrosine Kinase. Journal of Cellular Biochemistry 2008 105:497-502.

YASUHIRO M, ISAO OISHI, MITSUHARU ENDO, AND MICHIRU NISHITA. RorFamily Receptor Tyrosine Kinases in Noncanonical Wnt Signaling: Their Implications in Developmental Morphogenesis and Human Diseases Developmental dynamics, 2010. 239:1-15. 
